\title{
Assembling the Global Radical Waterfront
}

The 'Fighting International of the Radical Maritime Transport Workers' was to be officially inaugurated at a forthcoming world congress to be held in Hamburg on 20 May 1932, declared the 'Provisional' Executive Committee after its meeting in September $1931 .{ }^{1}$ Projected as a global manifestation of the radical waterfront, invitations were sent to both national unions and opposition groups. The ISH Secretariat initiated a global propaganda campaign, and published a special pamphlet outlining the agenda and objectives of the congress, see Figure 18. Ambitions were set high. The congress was to constitute a 'global front' against the shipowners's attempts to press wages and to deteriorate working conditions, against the threat of an impending world war, and in support of the struggles of the maritime transport workers in the colonial world. In line with the 'United front from below'-tactic, the pamphlet contained two messages. First, communist as well as non-communist members of the national maritime transport workers' union were incited to elect delegations for the congress. Second, and in line with the 'Confrontation'-tactic, the ITF was branded as being thew lackey of the shipping industry while the leaders of the national unions were denounced as traitors of the working class. ${ }^{2}$ Not surprisingly, the national unions refrained from responding, and the invitation mainly circulated in the communist press. ${ }^{3}$

A call signed by an 'International Committee' further underscored the projected global outreach of the congress. For an outside spectator (or police informant), it was just a list of names but an examination of the list reveals the composition of the collective ISH leadership and their regions of operations during spring 1932, see Table 10.

Meanwhile in Moscow, the RILU Budget Commission prepared an outline for the congress. It calculated a total of USD 20,00o to cover the expenses for 250 delegates for five days plus for an additional 100 participants for eight days. A special meeting at the RILU headquarters discussed the invitation of

1 Richtlinien an das Europäische Sekretariat, 18.10.1931, 534/4/347, 126, RGASPI.

2 Kleine Bibliothek der ISH, 20. Mai 1932 in Hamburg. Einheitskongress des Wassertransportproletariats der Welt (Hamburg: International of Seamen and Harbour Workers, no date [1931/32]).

3 Weiss, För kampen internationellt!, 187-189. 


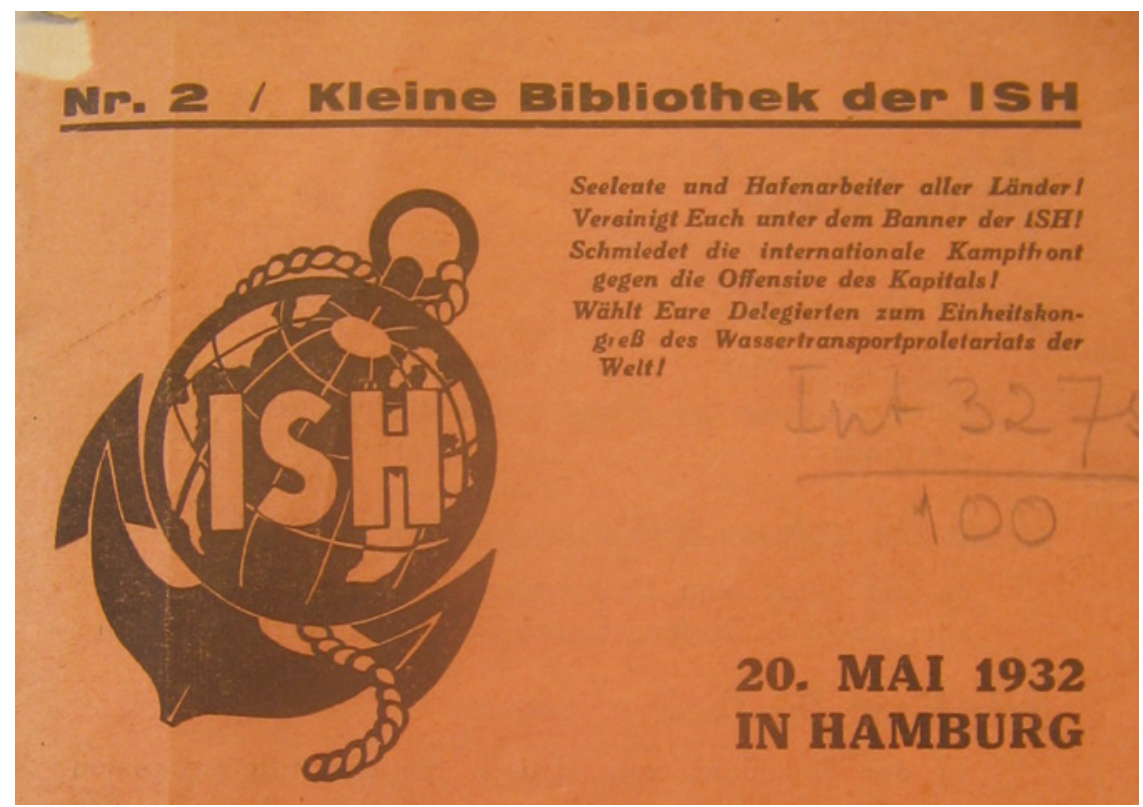

FIGURE 18 Calling the radical waterfront to meet at the world congress, pamphlet published by the ISH in spring 1932. The pamphlet publicised the agenda and the objectives of the forthcoming ISH World Congress.

black seamen and the RILU Budget Commission proposed ten delegates to be invited from Africa; however, the travel costs of 540 USD for two of the African delegates, one from Oran, the other from Sierra Leone, were to be covered by the ISH. ${ }^{4}$

Securing the participation of black seamen at the congress was in tandem with the RILU and ISH visions of mobilising black mariners into the revolutionary trade union opposition. In early January 1932, a high-ranking steering committee summoned in Moscow to outline the cooperation between the ISH and the ITUCNW in relation to the ISH World Congress. The main topic on the agenda was a proposal - perhaps authored by George Padmore - about bringing black seamen to the World Congress as well as establishing Interclubs in Africa (Freetown and Cape Town) and the Caribbean (Curaçao and Jamaica). While the question of establishing new Interclubs remained on the table, the meeting agreed that each of the delegations from Belgium, France, the Netherlands and the United Kingdom should include black members. Finally,

4 Kostenvorschlag zum 1. Weltkongress der ISH, 534/8/157, 192, RGASPI. 
TABLE 10 Geographic composition of ISH leadership by spring $193^{2}$

\begin{tabular}{|c|c|c|}
\hline Name published in $193^{2}$ call & $\begin{array}{l}\text { Country published in } \\
193^{2} \text { call }\end{array}$ & $\begin{array}{l}\text { Not mentioned in } \\
193^{2} \text { call }\end{array}$ \\
\hline Walter & ISH Secretariat & \\
\hline Hardy, Thompson & England & SMM \\
\hline Hudson, "Hink" [i.e., Mink] & USA & MWIU \\
\hline $\begin{array}{l}\text { Woll Weber [i.e., Wollweber], } \\
\text { Volkman }\end{array}$ & Germany & Einheitsverband \\
\hline Kouyaté, Blankaert, Olivier & France & FUMP \\
\hline Kobayashi & Japan & \\
\hline Alvarino & Latin America & \\
\hline Kommissarenko & Soviet Union & UWTW \\
\hline Ratti & Italy & FILM \\
\hline Raoul Martinez & Portugal & \\
\hline Nunez & Spain & \\
\hline Schaap & Holland & RTUO \\
\hline Verkeest & Belgium & RTUO \\
\hline Samsing & Norway & RFO \\
\hline Jensen & Denmark & $\mathrm{RFO}$ \\
\hline Persson & Sweden & $\mathrm{RFO}$ \\
\hline J. Shuba & South Africa & \\
\hline Liao & China & CSA \\
\hline Bart [i.e., Barth] & Danube countries & RTUO \\
\hline
\end{tabular}

SOURCE: “APPELL TILL SJÖTRANSPORTARBETARNA INFÖR SJÖTRANSPORTARBETARNAS FÖRSTA VÄRLDSKONGRESS," NY DAG 26.4.1932

the steering committee commissioned Garan Kouyaté to present a report on the colonial question at the congress. ${ }^{5}$

Preparations for the congress were in full swing by March 1932. Most sections had responded positively and had started to nominate delegations, see Figure 19. The documents prepared by the RILU Secretariat for the congress,

5 Huiswoud to Padmore, [Moscow] 6.1.1932, 534/3/753, 33, RGASPI. The Surinamese-born Communist Otto Huiswoud had replaced Padmore in fall $193^{1}$ as head of the RILU Negro Bureau. 


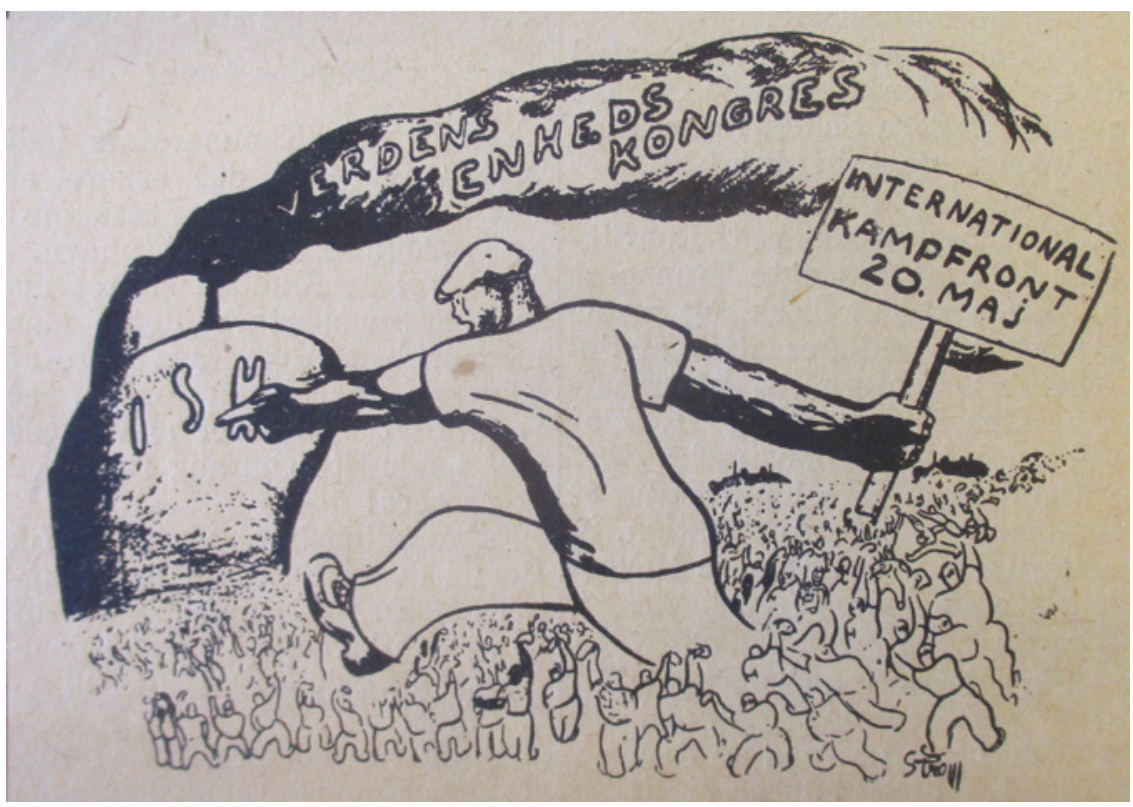

FIGURE 19 The radical waterfront heading towards Hamburg, illustration titled "International kampfront" (International fighting front), published in Rød Kurs 2 (May 1932).

including the resolution and statutes of the ISH, arrived in early April. Pechmann was pleased, and notified that the ISH instructors in Belgium, France, the Netherlands and Spain did their best to propagate for the congress, and that a fifth instructor was about to be sent to Greece. ${ }^{6}$

However, three of the national sections seemed to have severe problems. News from England continued to be disturbing, Hardy and Thompson quarrelled, and the SM M had not even started its campaign for the congress. Albert Walter therefore rushed to London for a serious discussion with the SMM leadership. ${ }^{7}$ In France, the ongoing reorganisation of the FUMP had a negative impact on the campaign and it only started after the removal of Auguste Dumay from his position. ${ }^{8}$ Interestingly, this might explain why his name is missing in Table 10. Disappointing news were also received from Vladivostok

6 Leo [Pechmann] to "Werte Genossen," [Berlin] 22.4.1932, 534/4/405, 210 - 213, RGASPI.

7 Heckert to "Lieber Alexander" [Lozovsky], Berlin 9.3.1932, 534/4/405, 148 - 151, RGASPI; Leo [Pechmann] to "Cher Camarades," [Berlin] 22.3.1932, 534/4/405, 167-168, RGASPI.

8 Leo [Pechmann] to "Werte Genossen," [Berlin] 19.4.1932, 534/4/4O5, 184-186, RGASPI. 
where the ISH representative had failed to get in contact with the illegal/ underground ISH section in Japan. ${ }^{9}$

Lozovsky reacted to the problems of enlisting participants to the ISH World Congress by asking the ECCI to interfere. The latter, in turn, ordered Lozovsky to nominate a commission to lead the congress, and to telegraph the British, Czechoslovakian, French, German, Polish, and US American parties and urge them to nominate delegations to the congress. The decision of the composition and sending of a delegation from the Soviet water transport workers' union, however, was a matter of Soviet Party, not the RILU, the ECCI reminded. In addition, the ECCI ordered the RILU Secretariat to draft a condemnation of the ITF for its rejection to participate at the congress, which was to circulate after the congress. ${ }^{10}$

Negative news added up in April 1932 when Walter informed Pechmann at the RILU Berlin Bureau that the local authorities had rejected his application to organise a congress in Hamburg. This must have come as a surprise as none of the comrades had even considered the possibility of a negative reply by the Hamburg police. Pechmann suspected that the rejection was due to a French intervention. Walter had to find a new location for the venue and travelled to Copenhagen to discuss the matter with Richard Jensen. Their solution was to move the congress to the Danish capital but they decided not to issue an official declaration about the decision. Instead, Hamburg was to remain as the location of the venue as long as the Danish authorities considered Jensen's application. ${ }^{11}$

The RILU headquarters in Moscow accepted the plan to move the congress to Copenhagen in early May but reminded the organising committee about necessity for it to be a legal event. In case of a negative answer from the Danish authorities, the RILU Secretariat urged the organisers to prepare an alternative plan for the venue if Copenhagen turned out to be impossible. ${ }^{12}$

At this point, the RILU Secretariat had finished its instructions for the congress and Lozovsky presented them at a meeting of the ECCI Political Commission in early May. A critical paragraph was the affiliation of the ISH with the RILU, and the ECCI underscored that the paragraph had to be reformulated as to leave the decision open, i.e., not to be decided by ISH Congress.

9 Report from Kennedy to Johnson, [Vladivostok] 14.2.1932, 534/4/415, 29, RGASPI.

10 Protokoll (A) Nr 234 der Politischen Kommission des E KKI der Sitzung am 9.4.1932, 495/ 4/182, RGASPI.

11 Leo [Pechmann] to "Werte Genossen," [Berlin] 22.4.1932, 534/4/405, 201-213, RGASPI.

12 See §19, Instruktionen für die Kommission zur Leitung des Internationalen Kongresses der ISH, 11.5.1932, 534/5/232, 35, RGASPI. 
Instead, the paragraph was to indicate that the ISH was closer to the RILU than the IFTU (Amsterdam International). Hoping for at least some 'reformist' delegates to participate, the ECCI ruled that if they did not oppose to the idea of an affiliation, the Congress was to authorise the ISH Executive Committee to start negotiations with the RILU. However, the final decision abour the ISH's affiliation with the RILU was to be made at the congress following the impeding one. To ensure the realisation of the plan, the ECCI ruled that the majority of members nominated for the ISH Executive Committee were supporters of the RILU. ${ }^{13}$ The decision of the ECCI was a somewhat desperate attempt to present the ISH in public as an 'independent' organisation and to blur its subordination to the RILU. Obviously, the ECCI strategists believed that the $193^{2}$ IS H Congress would nominate a leadership whose composition the RILU had prepared in advance, and that a following world congress, perhaps to summon in 1933 or 1934, would ratify the affiliation. While the first part of the plan materialised, the second part never did. Officially, therefore, the Is $\mathrm{H}$ never affiliated to the RILU but remained an 'independent' organisation.

Meanwhile in Hamburg, the organisers were approaching the final phase in their preparations. A (new) brochure in English, French, German, Norwegian, and Spanish containing the agenda and objectives of the congress was printed in 57,000 copies. ${ }^{14}$ News poured in at the ISH headquarters about positive responses to the international campaign for the congress - the water transport workers in Portugal declared their participation, the harbour workers' union in Cape Town had elected a delegation but the authorities had barred them from leaving South Africa, and unions in Cuba, Iceland, New Zealand, and Peru had been in contact with the IS H. ${ }^{15}$ Activities and collections in support of the congress were arranged by the Interclubs and the revolutionary oppositions in Belgium, Denmark, France, Germany, Norway, Poland, Sweden, and Switzerland. ${ }^{16}$ Government authorities, in turn, responded by denying passport to delegates bound to Hamburg. ${ }^{17}$ For a moment it even seemed that the organisers had to cancel the congress as the Danish authorities - hardly

\footnotetext{
13 Protokoll (B) Nr 240 der Politischen Kommission des EKKI der Sitzung am 9.5.1932, 495/ 4/188, RGASPI.

14 Bericht Polizeipräsident Berlin, 15.6.1932, Berichtserstatter Regierungsassessor Dr. Arian, Abt. 301 Akten des Ober-Präsidiums der Provinz Schleswig-Holstein betreffend die KPD, 4534, LAS.

15 "In Kapstadt, Peru, Kuba, Island," Hamburger Volkszeitung 14/15·5.1932.

16 "Seeleute und Hafenarbeiter in allen Ländern rüsten zum Weltkongress!," Hamburger Volkszeitung 17.5.1932.

17 "Hafenarbeiter in Dünkirchen erzwingen Ausstellung von Pässen," Hamburger Volkszeitung 18.5.1932.
} 
surprising -rejected the application. Walter hurried to Altona, a town next to Hamburg but administratively part of Prussia, and conviced the local police authorities to permit the congress to convene on Prussian territory. ${ }^{18}$

The announcement of arranging the congress in Altona caused great exitement among the communists in Hamburg. "The delegates of the congress will be the guests of the Hamburg proletariat," the Hamburger Volkszeitung enthusiastically declared. ${ }^{19} \mathrm{~A}$ few days later the tone changed to the opposite - the police authorities had also prohibited to summon the congress in Altona!20 "International" protests followed, organised by the Interclub in Hamburg, 500 protesting..${ }^{21} \mathrm{~A}$ new announcement followed on 20 May: The ban had been revoked!22 The communist press exulted: The organisers had managed to evade the prohibitons enforced by the social democratic trade union leaders and their symphatisers among the Hamburg police auhtorities. ${ }^{23}$

\section{A Global Moment: Altona, 21-24 May 1932}

Despite police harassment and all sorts of difficulties, 173 delegates representing 31 nations managed to arrive in Altona. The communist press hailed the congress as the global moment of the unified radical waterfront. ${ }^{24}$ The congress transgressed racial and political barriers and articulated international proletarian solidarity, trumpeted the ISH:

In complete unanimity the delegates of all races and nationalities participated in the discussion of the problems in regard to the organisation of economic struggles, the fight against imperialist war, the support of the

18 Kongress der ISH, 534/5/232, 75-76, RGASPI; "Der Kongress tagt in Altona," Hamburger Volkszeitung 12.5.1932.

19 "Hallo! Die Delegierten des Welteinheitskongresses der IS H sind die Gäste des Hamburger Proletariats," Hamburger Volkszeitung 12.5.1932.

$20 \quad$ "ISH-Kongress auch in Altona verboten!," Hamburger Volkszeitung 18.5.1932.

21 "Seeleute aller Länder protestieren gegen Verbot des ISH-Kongresses," Hamburger Volkszeitung 19.5.1932.

22 "Verbot des Kongresses der Wassertransportarbeiter aufgehoben," Hamburger Volkszeitung 20.5.1932.

23 "Rot Front den Wassertransportarbeitern der Welt!" Hamburger Volkszeitung 21/22.5.1932; "Internationaler Kampfkongress gegen Krieg," Arbeiter-Illustrierte Zeitung XI, no. 24 (1932): 568 .

24 "Internationale Kampfeinheit gegen Hunger und Krieg," Hamburger Volkszeitung 23.5.1932. 
doubly exploited and suppressed colonial comrades standing before the Congress." 25

Half of the delegations represented the revolutionary trade union opposition and red unions, the RILU Berlin Bureau noted, the other half comprised of representatives from "reformist" or syndicalist unions. ${ }^{26}$ Some of the delegates represented ITF-member unions, communist observers noted; the delegate of the Danish Seamen's Union even announced that his union just recently voted for affiliating to the ISH, while the delegates from the Danish Stokers' Union and the local union of maritime transport workers in Seville informed that their unions were about to vote leaving the ITF. Clearly, the impression was that the ISH was about to break the ranks of the ITF, see Figure $20 .{ }^{27}$

The Prussian police authorities in Berlin were perplexed when hearing about the congress as they would never have accepted the application for organising the venue. The local police authorities received harsh criticism about their blunder to revoke the ban. The police authorities in Berlin bashed the local police for having failed the recognise that it was a venue where militant radicals convened, some of them publicly known as notorious infesters of suspicious communist and Bolshevik propaganda. Even worse, discrepancies existed in Altona and Berlin about the exact number of participants, local police informants in Altona claimed 242 persons participating while the Berlin police authorities only listed 189 participants. The list prepared by the local police in Altona counted 186 foreign delegates of which only one, Kommissarenko, represented Soviet Russia, while the Berlin police authorities listed only 79 foreigners including a 25-person Russian delegation (although this information was later corrected: only Kommissarenko had participated at the congress).$^{28}$ However, the different numbers reflect the daily fluctuations of participants at the congress as was reflected in the two lists of delegates prepared by the ISH, see Table 11.

An analysis of the composition of the delegations indicates the uneven outreach of the ISH. More than half of the mandated delegates originated from Germany and the Scandinavian countries, indicating the relative weight of

25 The World Unity Congress of the International Water Transport Workers and its Decisions (Hamburg: International of Seamen and Harbour Workers, no date [ca. 1932]), 4.

26 Kongress der ISH, 534/5/232, 75, RGASPI.

27 The World Unity Congress of the International Transport Workers: 4.

28 Dr. Klaussner, Preuss. Ministerium des Inneren an d. Herrn Regierungspräsidenten in Schleswig, Berlin, 27. Juni 1932, Zum Bericht vom 1. Juni 1932 betr. ISH Kongress, Abt. 301 Akten des Ober-Präsidiums der Provinz Schleswig-Holstein betreffend die KPD, 4534, LAS. 


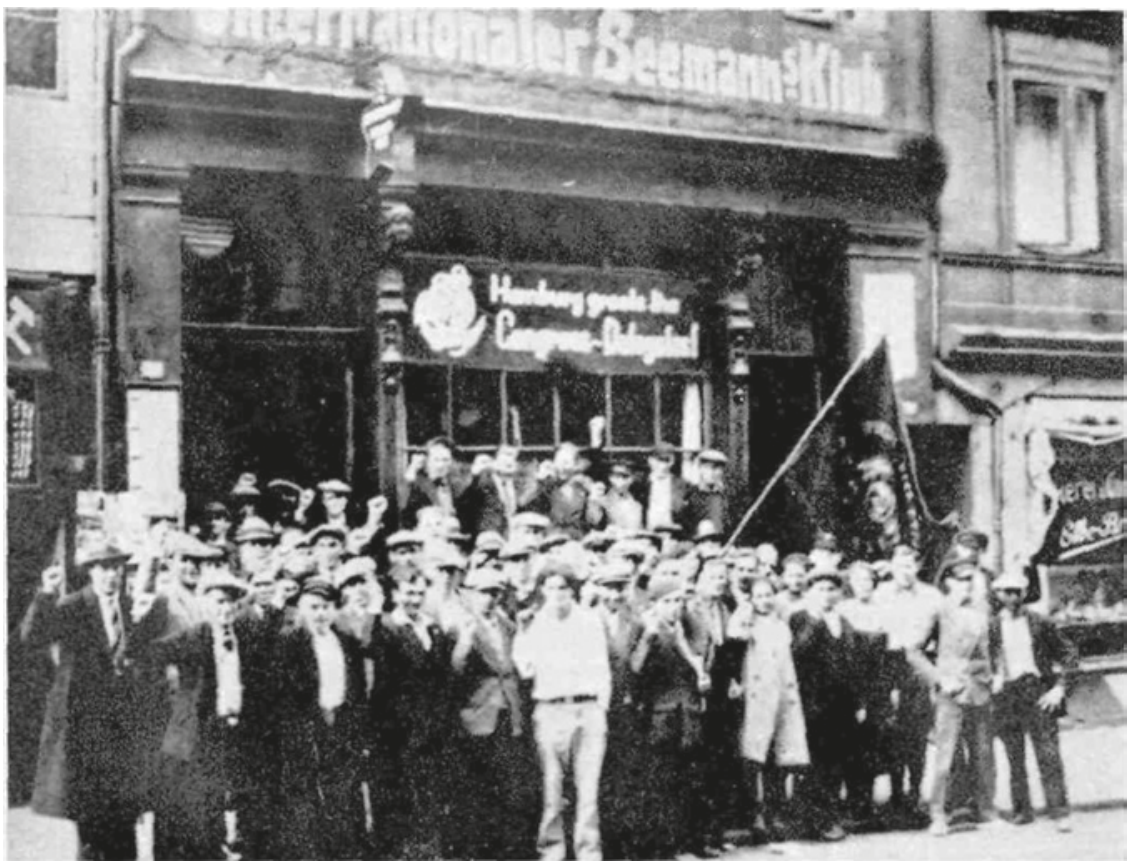

FIGURE 20 Seamen giving the clenched-fist salute in front of the International Seamen's Club at Rothesoodstrasse during the Is H World Congress. The photograph was taken in 1932 by an unknown photographer. It was not published in the proceedings of the congress. About twenty years later, it was published in the ITF-monthly International Transport Workers'Journal XIV, no. 4 (April 1954): 6o.

these sections within the ISH. Most of the delegations comprised only a few members due to the high expenses of traveling to Hamburg. Some organisations, such as the fishermen's association in Havana, had no financial means at their disposal for sending a delegate. ${ }^{29}$ Others, such as the Australian delegate, were delayed and only arrived after the congress had closed, while a representative from South Africa was claimed to have participated but was not listed among the mandated members, see Figure $21^{30}$

29 "30 Schilling von den Fischern in Havanna für den Weltkongress," Hamburger Volkszeitung 18.5.1932.

30 Leo Braun, Über den Kongress der Seeleute, 2.6.1932, 534/5/405, 242, RGASPI. The identification of Leo Braun is unclear. It could be an alias of Pechmann who participated at the congress, or refer to another person at the RILU Berlin Bureau who used the name/alias of Braun, sometimes also Brown. 
TABLE 11 Delegates at the 1932 ISH World Congress

\begin{tabular}{|c|c|c|}
\hline & LAS1 & LAS2 \\
\hline Sweden & 12 & 15 \\
\hline Iceland & 1 & 1 \\
\hline Latvia & 2 & 3 \\
\hline Poland & 1 & 1 \\
\hline Austria & 2 & 3 \\
\hline Hungary & 1 & 1 \\
\hline Czechoslovakia & 1 & 1 \\
\hline Netherlands & 6 & 6 \\
\hline [French] Indochina & 1 & \\
\hline China & 2 & 3 \\
\hline Norway & 11 & 11 \\
\hline Estonia & 2 & 1 \\
\hline Finland & 1 & 1 \\
\hline Romania & 1 & 1 \\
\hline Italy & 2 & 3 \\
\hline Spain & 1 & 1 \\
\hline Greece & 1 & 1 \\
\hline [Belgian] Congo & 1 & \\
\hline Somaliland & 1 & \\
\hline Switzerland & 1 & 1 \\
\hline Indonesia & 1 & 1 \\
\hline Denmark & 21 & 22 \\
\hline Portugal & 3 & 3 \\
\hline France & 8 & 9 \\
\hline Belgium & 6 & 6 \\
\hline Japan & 2 & 2 \\
\hline Sovjet Union & 1 & \\
\hline United Kingdom & 8 & 7 \\
\hline Germany & 45 & 56 \\
\hline USA & 9 & 8 \\
\hline Danzig & 1 & 1 \\
\hline
\end{tabular}


TABLE 11 Delegates at the 1932 ISH World Congress (cont.)

\begin{tabular}{lll}
\hline & LAS1 & LAS2 \\
\hline Algeria & & 1 \\
Yugoslavia & 1 \\
In total & 156 & 171 \\
\hline
\end{tabular}

SOURCE: LAS1= ABSCHRIFT. VERTRETEN SIND DELEGIERTE AUS FOLGENDEN LÄNDERN, MATERIAL DES KONGRESSES DER ISH VOM 21-24.5.1932, POLISEIPRÄSIDENT ALTONAWANDSBEK, 1.7.1932, ABT. 301 AKTEN DES OBER-PRÄSIDIUMS DER PROVINZ SCHLESWIGHOLSTEIN BETREFFEND DIE KPD, 4534 (1932-1933), LAS; LAS2= MANDATSPRÜFUNGSKOMMISSION, PROTOKOLL DES 1. WELT-EINHEITS-KONGRESSES DER REVOLUTIONÄREN WASSERTRANSPORTARBEITER, ABT. 301 AKTEN DES OBER-PRÄSIDIUMS DER PROVINZ SCHLESWIG-HOLSTEIN BETREFFEND DIE KPD, 4534 (1932-1933), LAS

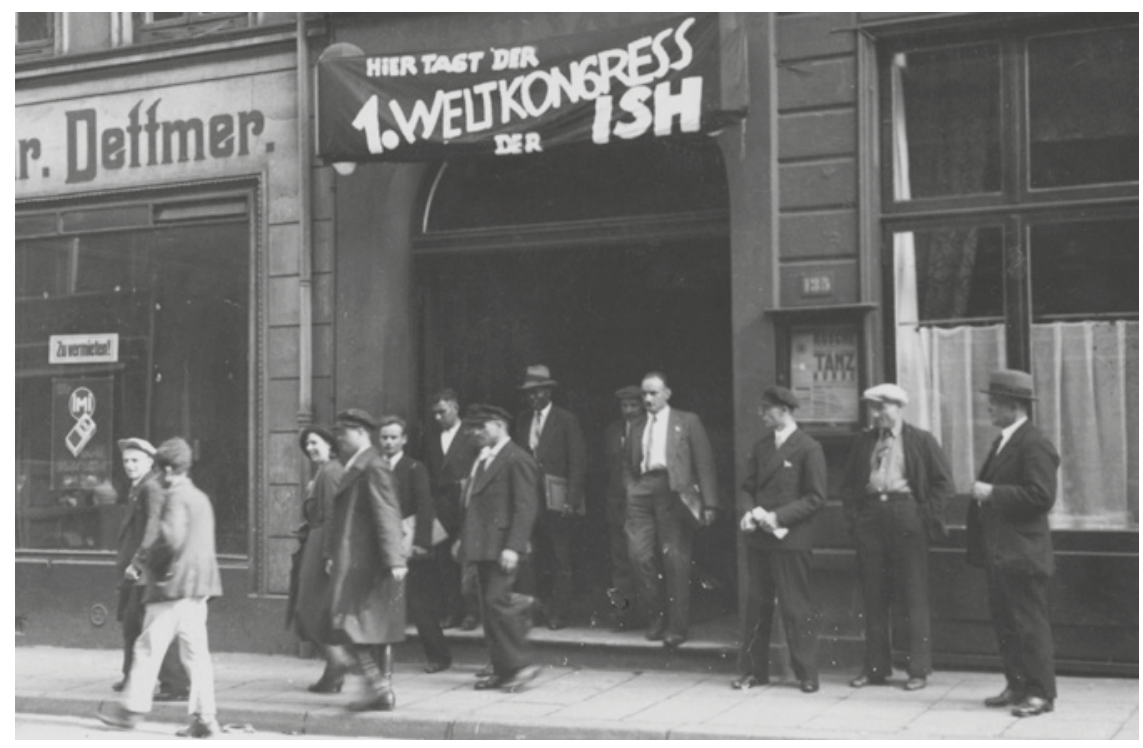

FIGURE 21 Delegates leaving the premises of the congress venue. The ISH World Congress convened at the convention hall Papstsälen in Altona. In fact, the illustration is a postcard, probably produced during the congress by the ISH, source: Sammlung Rene Serenko, Hamburg. The postcard carries no information of the publisher or photographer. The banner above the entrance carries the text: Hier tagt der 1. Weltkongress der ISH (Here convenes the First World Congress of the ISH). René Seneko kindly forwarded a digital copy of postcard to me. The individuals on the photograph have not yet been identified, at least one of them being a black delegate, another a female participant. See also "Objekt: 1932_ish" at http:// niqolas.de/postcard-social.de/1926 (checked 16.12.2020). 
The most important task of the congress was to nominate a 35-member executive committee as well as to confirm the statutes and organisational structures of the ISH. As noted above, the RILU Secretariat had prepared the documents and, not surprisingly, the congress unanimously adopted them. While the statutes were published in the congress publication, the composition of the executive committee was never publicised. Neither was there any official announcement about a change in the IsH leadership and the abolishment of the post of ISH president. In effect, George Hardy was deposed - in fact, he was not even elected to the new executive committee, see below - and Albert Walter, as ISH Secretary, came out as the new head of the organisation. Internal documentation give some hints about the composition of the new executive committee which, among others, included Ernst Wollweber (Germany), Joseph Schaap (Netherlands), Garan Kouyaté and Wymiens (France), Alec Robson and Joe Keenan (England), Nunez (Spain), Barth (Austria/Danube Committee), Richard Jensen and Borglund (Denmark) as well as three unidentified members from Norway, Sweden and the USA. ${ }^{31}$

The congress discussed three major themes; the congress publication included at least shortened versions of the three reports, see Figure 22. Each of them starting with a general thematic presentation, followed by lengthy discussions, and ending with the adoption of a resolution (which had been prepared in advance in Moscow). Albert Walter opened the first theme by giving an overview of the concurrent crisis of the shipping industry and the necessity of a united front among the maritime transport workers. Tommy Ray ${ }^{32}$ from the USA spoke about the fight against the Japanese invasion in Manchuria and the impending war against the Soviet Union. Garan Kouyatés report on the organisation of the colonial maritime transport workers' fight for economic justice opened the third theme..$^{33}$

31 Walter to "Werte Genossen," Hamburg 2.12.1932, 534/5/231, 78, RGASPI. The ISH Executive Committee had a meeting in Amsterdam at the end of August 1932 to discuss the launching of a new international campaign for full employment on board the ships and in the harbours. However, apart from a press clipping, I have so far not found any documentation on the meeting. See "Internationale Aktion des Wassertransportproletariats," Internationale Gewerkschafts-Presse-Korrespondenz 70 (1933), enclosed in Nachrichtensammelstelle R.M.I., Betrifft: Internationale der Seeleute und Hafenarbeiter (Streikvorbereitungen), Berlin 5.10.1932, RAV Botschaft Moskau 196, PAAA.

32 Stated as 'Rey' in the published report of the congress whom I identify as Tommy Ray who represented the MWIU.

33 The texts to the [Resolution on] 'The Situation of the Water Transport Workers and the Creation of the International Unity Front for Struggle against Shipping Capital', [Resolution on the] 'Struggle against Imperialist War', and 'Resolution on the situation and struggles of the seamen and harbour workers in the colonial and semi-colonial countries and the tasks of the sections of the IsH', were published in The World Unity Congress. 


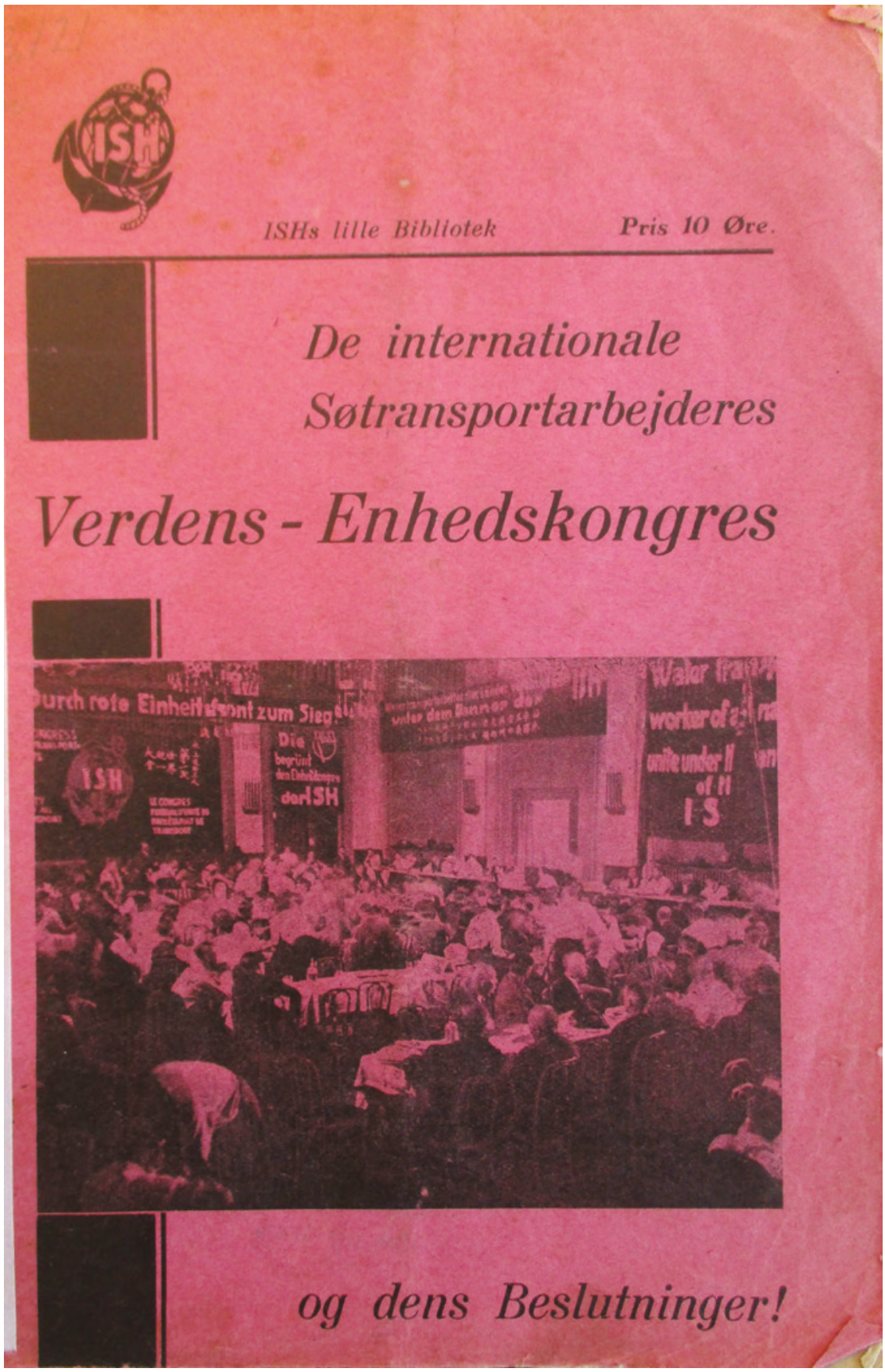

FIGURE 22 The published proceedings of the ISH World Congress. The proceedings were published in Danish, English, and German, at least. 
The congress itself proceeded on three levels. Large plenary sessions were held where a wide range of themes were discussed, such as unjust living and working conditions on board the ships, and demands for seven-hour working days and a just salary. Another theme was the right to establish and join unions as well as the right to strike on board ships (hitherto prohibited by maritime law), strike techniques, and under what circumstances one should pursue specific strike tactics. A third general theme was the positions of seamen a future conflict or even war; a fourth theme was the potential of the revolutionary trade union opposition for gaining more influence in socialist-controlled unions. In general, the discussions ended in the adoption of "demand programmes" which had been prepared in advance at the RILU headquarters. ${ }^{34}$

Apart from large plenary sessions, special commissions on work among Baltic, British and colonial mariners organised their own closed meetings and sub-conferences, see below. In addition, a special conference for women was organised on Sunday 22 May; 35 unfortunately, not much is known about it. The conference for young maritime transport workers numbered twelve participants, convened parallel to the congress, and resulted in the establishment of a specific Youth Commission and the adoption of directives for work among the maritime youth. ${ }^{36}$ Last, but not least, the inner circle of the communists and

34 The following "programmes of demand" circulated at the congress (and a copy of them had been obtained by the finks of the police in Altona): Internationales Förderungsprogramm der Binnenschiffer [International programme of demands for river transport workers], Kampfprogramm der Partikulier-Schiffer [Programme of demand for private river skippers], Kampfforderungen der Wasserbauarbeiter [Programme of demands for water construction workers], Internationales Forderungsprogramm der Hochseefischer [International programme of demands for offshore fishermen], Internationales Forderungsprogramm der Hafenarbeiter [International programme of demands for harbour workers], Internationales Forderungsprogramm der IsH für die Seeleute [International programme of demands for seamen], and Vorschläge für ein Kampfprogramm der Küstenfischer [Suggestions for a programme of demands for coastal fishermen], draft versions included in: Polizeipräsident Altona-Wandsbek, 1.7.1932, Material des Kongresses der ISH vom 21-24.5.1932, Abt. 301 Akten des Ober-Präsidiums der Provinz Schleswig-Holstein betreffend die KPD, 4534, LAS.

35 "Frauen kämpfen gegen Krieg und Hunger!," Hamburger Volkszeitung 18.5.1932; "Frauen der Seeleute und Hafenarbeiter: Lohnfrage des Mannes - ist die Brotfrage der Frau!," Hamburger Volkszeitung 21/22.5.1932.

36 Entwurf über die Lage der jugendlichen Wassertransportarbeiter und die Aufgaben der ISH und ihrer Sektionen, no date [1932], 534/5/231, 179-186, RGASPI; "Resolution of the Youth Commission of the Unity Congress of the International Water Transport Workers," published in The World Unity Congress. 
trusted activists gathered held behind the curtains out of sight of the public and non-invited delegates. ${ }^{37}$

\subsection{Opening the Baltic Dimension}

Scandinavia and the Baltic region constituted a promising arena for the ISH. After the dissolution of the Scandinavian Secretariat in early spring 1931, the ISH Secretariat established direct links to its national sections in Denmark, Norway and Sweden. One year later, it drafted a plan for connecting with opposition groups in the Estonian, Finnish and Latvian seamen's unions. ${ }^{38}$ A first step was the publication of journals in the name of fictive ISH sections in spring 1932, see Figure 23; the next one was to summon delegates from the Baltic region to the World Congress. The plan materialised although only the Finnish delegate came from his home country whereas the five Estonians had arrived from Antwerp and Rotterdam. The Latvian delegation was the largest one, comprising of eight members, probably also arriving from Northern European ports. Walter held a meeting with the so-called 'Baltic delegation' in conjunction with the World Congress to discuss strategic and tactical matters. As an outcome, the 'Baltic Committee' was set up at Rothesoodstrasse. Its main task was to coordinate the activities of the Baltic sections of the Interclubs in Antwerp, Danzig, Hamburg, and Rotterdam. ${ }^{39}$ Operations of the Baltic Committee commenced in September when L. Avotin, a.k.a. Ernest Lambert, started as its head. ${ }^{40}$

Another important operational field of the ISH was Denmark as the Danish Straits were the lock to the Baltic Sea. The Is H Secretariat must have regarded organisational developments in Denmark as highly promising. The Søtransportarbeidernes RFO, the Danish section of the ISH, announced the expansion of the revolutionary opposition in the maritime unions in Denmark at its second national conference in March 1932. Counting 800 members and 31 ships cells, the stage was set for its next goal, namely the conquest of union leadership and the affiliation of the unions with the Is H. Main attention was at first towards the Danish Seamen's Union whose social democratic leadership

37 Erik Nørgaard, Revolutionen der udeblev. Kominterns virksomhed med Ernst Wollweber og Richard Jensen i forgrunden (København: Fremad 1975), 94-95; Eiber, Arbeiter und Arbeiterbewegung, 183-184.

38 Walter/Stein/Adolf, Vorschläge zur Stärkung der organisatorischen Arbeit der ISH, Hamburg, 1.3.1932, 534/5/230, 53, RGASPI.

39 Walter, Bericht über die Konferenz der Baltischen Sektion der IS H, die vom 19-21 Mai 1932 in Hamburg tagte, 534/5/232, 36-37, RGASPI.

$40 \quad$ Minutes 23.9.1932, 23.11.1932, Ernst Lambert (Avotin) personal file, KV 2/3729, TNA. 


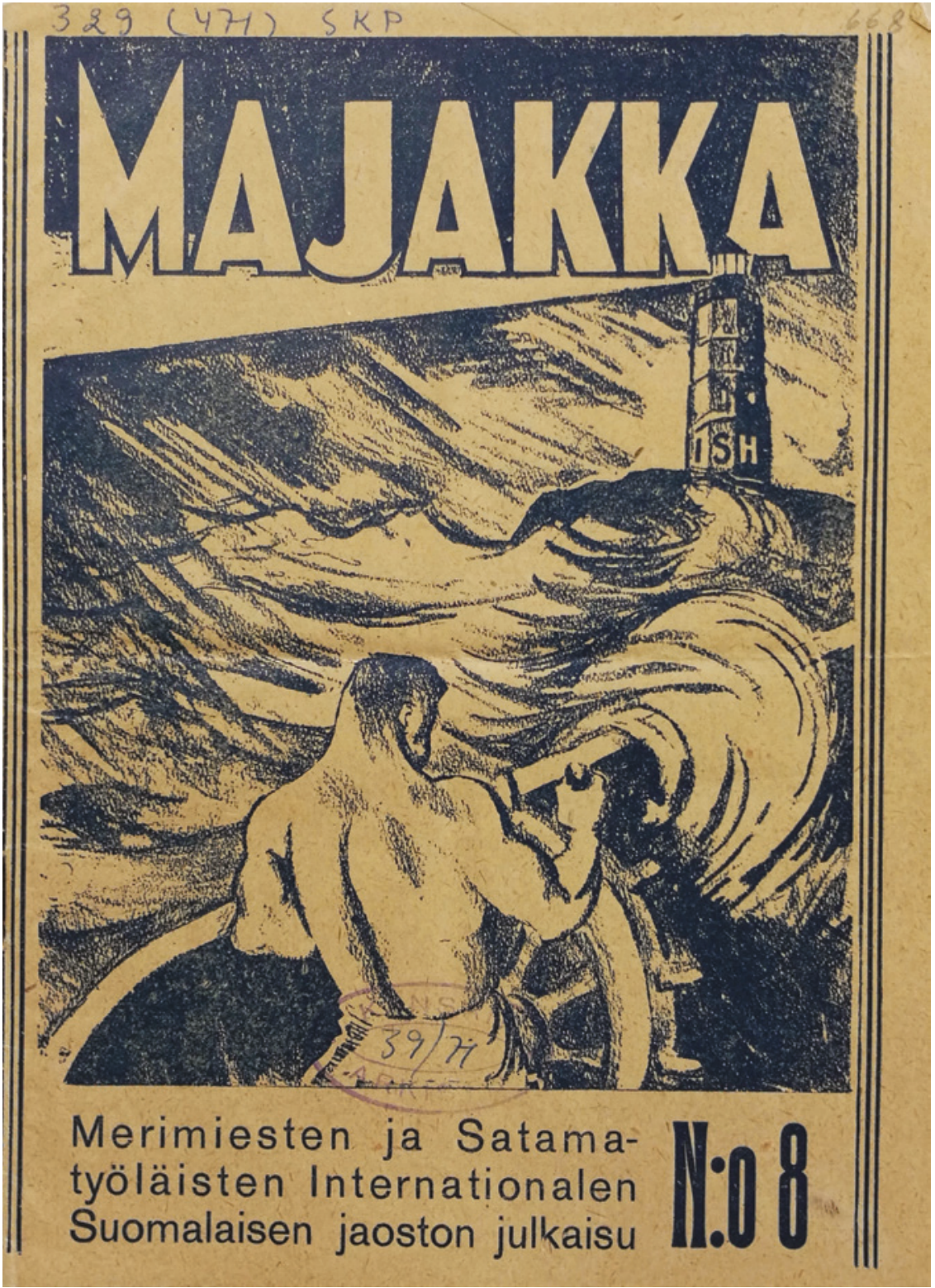

FIGURE 23 Majakka, the organ of the (non-existing) Finnish section of the ISH. 
only narrowly had repelled an attempt by the opposition to cut the unions ties with the ITF and to affiliate with the ISH in November 1931. The opposition initiated a new vote half a year later, and to the surprise of the union leadership, the opposition managed to rally a majority behind their proposition. However, the cheers at the IsH World Congress proved premature as the union leadership organised a vote to revoke the decision. What followed was a propaganda war carried out in union and opposition journals. ${ }^{41}$ The IsH Secretariat intervened at the end of the year by sending a stiff reprimand to the Danish Party and the DKP sea cell, criticising them for applying the wrong tactic. Above all, it was a mistake to present the ISH in public as a communist international. Instead, the ISH Secretariat urged the Danish comrades to disguise any links between the party and the IS $\mathrm{H}$, and to launch a counter-campaign signed by "a group of ISH-supporters." The counter-campaign was to present the ISH as an independent, non-aligned platform with no links to the Comintern or the RILU. ${ }^{42}$

Meanwhile, the Danish stokers' union - already dominated by the communists with Richard Jensen playing the role as grey eminence - had voted for affiliating with the ISH in May 1932 but the social democratic union leadership managed to postpone the decision. ${ }^{43}$

Apart from the tense situation in Denmark, the Is H Secretariat was aware of the expiration of tariffs in Denmark, Finland and Sweden at the end of 1932. In all three countries, the shipowners had announced drastic reductions in wages. Anticipating tough negotiations and the potential for the revolutionary opposition to take a leading role in upcoming strikes, Walter summoned the representatives of the Scandinavian opposition for a conference in Copenhagen in early January $1933{ }^{44}$

\subsection{Exit George Hardy}

Communist agitation and propaganda among the maritime transport workers had a complex if not complicated history in Britain. The formation of Interclubs and revolutionary nuclei had never been successful, neither had the revolutionary opposition any strong position within the national unions. The British Party had been lukewarm in rendering support to work among maritime transport workers, partly as it lacked both functionaries and funds. The Minority Movement had been late in organising a special unit for work among

\footnotetext{
41 Weiss, För kampen internationellt!, 274, 313-314.

42 ISH Sekreratiat to DKP Central Committee, 1.12.1932, 534/5/231, 117a-199, RGASPI.

43 Weiss, För kampen internationellt!, 315 .

44 Walter to "Werte Genossen," 2.12.1932, 534/5/231, 79, RGASPI.
} 
seamen and had repelled all propositions from the RILU, the IPAC-TW and the ISH to transform the Seamen's Minority Movement (SMM) into a genuine red union.

The IsH Secretariat announced George Hardy's return to England in early June 1931 to be a new injection for the campaign to establish a red seamen's union in Britain. Soon, however, discouraging news reached Hamburg. In early autumn, Hardy and Fred Thompson had to acknowledge the fact that the initial timetable for forming the new union in September was unrealistic. Hardy informed the ISH Secretariat that the project had to be postponed as the SMM lacked a sizeable membership and efficient functionaries and cadres; ${ }^{45}$ a few days later, the Minority Movement confirmed Hardy's statement. ${ }^{46}$

Prompted by the negative news, the ISH Secretariat made its own assessment about the situation in England and seemed to have lost confidence in Hardy already during autumn 1931. Hardy, in turn, realised this and confronted Walter by asking how one should interpret the sentence "When you were President of the IS H" in Walter's letter? If he had been dismissed from his post, then surely the comrades in Hamburg could tell him when and why this decision had been made, Hardy reasoned. ${ }^{47}$ Walter did not respond. However, Walter, Pechmann and Shelley had probably already made up their mind to dump Hardy from the ISH leadership at the forthcoming World Congress.

Next, the IsH Executive Committee discussed the setbacks in Britain at its meeting in September 1931. Hardy decided not to attend, and his replacement Fred Thompson reported that he "did not do so well" at the meeting. Hardy's "dictatorial methods" were criticised by the ISH Secretariat, and British Intelligence sources believed that "he would have a rough time were he to return" to Hamburg. The main critique ("anger") was the postponing of the conference to launch the new union, and the ISH Executive Committee impelled Thompson to fix a new date and then to adhere to the plan. Thompson received USD 6oo to cover expenses for launching the new union and returned to England. 48

Nevertheless, in contrast to rumours in Hamburg and Berlin, Hardy still clung to the idea of launching a red seamen's union. Instead of attending the Is H Executive meeting, he was organising meetings and rallies as part of the campaign for a red union in Cardiff, Liverpool, South Shields and Swansea in August/September. When Thompson told him about the criticism at Hamburg,

45 Hardy to ISH Hamburg, London 1.9.1931, 534/4/379, 24-25, RGASPI.

46 NMM to ISH Hamburg, London 4.9.1931, 534/4/379, 21, RGASPI.

47 Hardy to IsH Hamburg, London 1.9.1931, 534/4/379, 24-25, RGASPI.

48 Report re SMM, 24.9.1931, George Hardy personal file, KV 2/1027, 47f, TNA. 
Hardy announced "[...] Time has arrived to do some plain talking about the statements regarding underestimation of the forces against us and the time for the national conference. [...] The more I think, the more I am convinced I should have gone to Hamburg."49

By mid-September 1931, it must have been evident for everyone but the communist die-hards that the red seamen's union was a stillborn idea. "My deductions are that at present the launching of a new Mm Seamen's Union would end in failure," a British Intelligence informant declared, and further noted "although Hardy and Thompson are pushed to do so by some of the militants in the ports, both are aware that the time is not ripe, owing to the lack of sufficient members, trustworthy officials and experienced organisers." 50 Nevertheless, Hardy and Thompson decided to continue the campaign - or was it just stubborn wilfulness from Hardy's side? "3,0oo Cardiff seamen have drawn up a list of demands which they were determined to see enforced and for that purpose it was proposed to form a new union, and if necessary, to call for a strike," Hardy boasted in mid-October. ${ }^{51}$ The question - and ultimate reason for the fallout between him and Thompson - was when this would occur.

Hardy and Thompson held different opinions on when to launch the new union; Hardy advocated a slow tempo, Thompson an enforced one. Soon they started to quarrel, and the leaders of the Minority Movement asked the CPG B to pay attention to "the peculiar circumstances surrounding Comrades Hardy and Thompson." ${ }^{52}$ News about the chaotic conditions at the SMM headquarters also reached the RILU European Bureau, and Pechmann commented upon the situation in England in a frustrated report to Moscow. ${ }^{53}$

Hardy's argument for delaying the establishment of the new union to December - as had been promised by Thompson at the ISH Executive Committee meeting in Hamburg - was tactical as he expected the TUC to back the NUS in its negotiations on cutting the wages of harbour workers and seamen. ${ }^{54}$ Hardy anticipated that the negotiations would cause a general outrage, and planned to present the new red union as the only defender of

49 (Half-burnt copy) Inf. note 25.9.1931, George Hardy personal file, KV 2/1027, TNA.

5O Report by "F.1," 15.9.1931, George Hardy personal file, KV 2/1027, 46a, TNA.

$5^{1}$ (Half-burnt copy) Inf. note 19.10.1931, George Hardy personal file, KV 2/1027, TNA.

$5^{2}$ (Half-burnt copy) Inf. note 30.10.1931, George Hardy personal file, KV 2/1027, TNA.

53 Leo [Pechmann] to "Werte Genossen," [Berlin] 21.11.1931, 534/4/353, 81, RGASPI.

54 See further Plan for mobilising the seamen for fight against the wage cuts, to strengthen the militant Seamen's Minority Movement and to build up the new seamen's union, no author, dated December 1931, copy attached to George Hardy's dispatch to Lozovsky, January 1931, filed in 534/7/54, 24-26, RGASPI. 
the maritime workers.. .55 The crux of the matter was how to read the 'signs of the hour' and when to strike. Thompson identified the attempt to cut the wages of the harbour workers in Liverpool as the momentum to launch the new union, declared 5 January 1932 to be the date for launching a strike, and ordered 60,00o leaflets dealing with the dockers' cuts and 10,00o union books with skeleton rules for a start. ${ }^{56}$ Hardy disagreed and went for Moscow to participate at the Eight Plenum of the RILU General Council in early December. ${ }^{57}$

The dispute in Liverpool ended in a fiasco. Hardy accused Thompson for having created a "hell of a mess" by the "constantly wrong approach by putting the Union before the struggle instead of developing the fight, and the Union out of it." ${ }^{\prime 8}$ Instructed by the ISH, Hardy took over the political leadership of the SMM and prepared for his own bravura - to organise a strike among the seamen and a complete stoppage of work on the Thames waterfront. ${ }^{59}$ On 2 February 1932, a meeting of 1,500 seamen voted for strike actions and Hardy announced "[...] Now it is the opportunity of the dockers to enter the struggle." ${ }^{\prime 0}$ They did not, and no other mariner did so either. Hardy's tactical manoeuvre, too, ended in a total fiasco. Tactics had to be changed, an assessment report by the SMM reasoned, and shelved the idea of launching a new union. ${ }^{61}$

The tug-of-war between Thompson and Hardy finally resulted in an intervention by Harry Pollitt. Many SMm members, he claimed, accused the two comrades for having "sabotaged" the projected union. Hardy answered by putting the blame on those who had concentrated too much on the new union instead of generating sufficient support for the strike. ${ }^{62}$ The first round ended with Thompson threatening to resign, stating that it was impossible to work with Hardy. ${ }^{63}$

News about the crisis in England reached the RILU Berlin Bureau in spring 1932, informing about clashes between Hardy and Thompson in the office of the

55 (Half-burnt copy) Inf. note 10.11.1931, George Hardy personal file, KV 2/1027, TNA.

56 (Half-burnt copy) S.B. note 31.12.1931, George Hardy personal file, KV 2/1027, TNA.

57 (Half-burnt copy) Inf. note 2.1.1932, George Hardy personal file, KV 2/1027, TNA.

$5^{8}$ British Intelligence report, 13.1.1932, George Hardy personal file, KV 2/1027, 66a, TNA.

59 (Half-burnt copy) Inf. note [... (December)]31, as well as Inf. Notes 20.1.1932 and 30.1.1932, George Hardy personal file, KV 2/1027, TNA.

6o (Half-burnt copy) Inf. note 2.2.1932, George Hardy personal file, KV 2/1027, TNA.

61 See further Minority Seamen's Movement, Lessons and tasks of the seamen's strike and the work of the Seamen's Minority Movement, no author, dated Poplar, London 16.3.1932, copy attached to George Hardy's dispatch to Lozovsky, January 1931, filed in 534/7/54, $27-$ 33, RGASPI.

62 (Half-burnt copy) Inf. note 15.2.1932, George Hardy personal file, KV 2/1027, TNA.

63 (Half-burnt copy) Inf. note 22.2.1932, George Hardy personal file, KV 2/1027, TNA. 
SMM in London. ${ }^{64}$ The conflict at the SMM headquarters resulted in an almost standstill of activities and compelled Fritz Heckert, head of the RILU Berlin Bureau, to intervene. Hardy and John Mahon of the Minority Movement were called to Berlin for consultations in early March 1932. The meeting decided to dissolve the SMм leadership and replace it with a dual secretariat composed of Hardy and Thompson. In addition, Heckert instructed the SMM to restrict its activities and to concentrate on work in Harwich, Liverpool, London, North Shields and South Shields. ${ }^{65}$

Hardy returned to London and notified the comrades about the decision made in Berlin of a collective leadership and the election of a small secretariat to lead the work of the SMM. ${ }^{66}$ Hardy proposed John Joseph McGrath as new leader of the SMM and himself as new secretary. Pollitt had to accept this intervention although it is unclear if he backed it. This was at least the impression by the British Intelligence informant: "All principals of the CPGB, including Pollitt, are disgusted with Hardy, but they cannot oust him. Pollitt told Thompson that he was more than sorry for him, but that orders from 'the other side' were to the effect that Hardy was given preference in the contention between him and Thompson." 67

Documentary sources are highly uneven to explain the course of events during spring and summer 1932. Special Branch informants claimed that Hardy declared already in March to shift the focus of the SMM towards building a strong opposition within the NUS. This would have meant a total deviation from the position of the ISH and RILU to establish a red union in Britain. Was this the ultimate reason for sending George Padmore on a mission to Britain in April? Hitherto researchers have interpreted Padmore's visit as part of his ambition to extend the network of the ITUCNW in Britain. ${ }^{68}$ Some of Padmore's correspondence in early 1932 points towards this direction. In January, Padmore sent a letter to John Mahon, asking him to "try your best to get Hardy to agree upon something concrete re our colonial work. The leading comrades are simply worrying my life out about the Mм on this matter. [...] As soon as I get word from GH [George Hardy] I shall let him know what colonies we should

64 [George Hardy,] Denkschrift über die politischen Differenzen zwischen den Genossen Hardy und Fred Thompson, 22.3.1932, 534/5/230, 71-75, RGASPI.

65 Fritz Heckert to Alexander [Lozovsky], Berlin 9.3.1932, 534/4/405, 148-149, RGASPI.

66 (Half-burnt copy) Inf. note 8.3.1932, George Hardy personal file, KV 2/1027, TNA.

67 (Half-burnt copy) Inf. note 7.3.1932, George Hardy personal file, KV 2/1027, TNA.

68 See further Adi, Pan-Africanism and Communism, 146; Weiss, Framing a Radical African Atlantic, 365 . 
concentrate upon."69 Seemingly not knowing that Hardy was fully occupied in campaigning for the seamen's strike, he received an answer from Hardy in early February which must have made a positive impression upon him: "Now that the ice is broken I intend to stick behind him until we get something definitively accomplished." 70

Who were the "leading comrades" and was the ice broken? It is likely that Padmore referred to the ISH and RILU bureaus in Hamburg and Berlin with whom he had been closely cooperating. However, planning for work among colonial seamen in Britain or reaching through them the colonies seemed to have been slow in materialising as Padmore informed the ISH Secretariat that he wanted to travel to England to clarify some organisational problems and asked for funding to cover his expenses. ${ }^{71}$

British Intelligence sources, however, claim that Padmore's main mission was to inspect the activities of the SMM. Perhaps the ISH and RILU bureaus had extended his original travel plans and mandated him to serve as their emissary? This seems to have been the case according to one of the informants:

Harry Pollitt has received definitive instructions that unless there are speedy tangible results, the whole of the CPGB leaders will be superseded. After this was made known the [ISH?/RILU?] Secretariat decided that GH [George Hardy] 'must go'. Padmore asked F[red] T[hompson] to resume his old position. The whole question will be thrashed out at the Congress in Hamburg in May. ${ }^{72}$

Whether Hardy ever met Padmore in April 1932 is not known. However, it must have been obvious for everyone that the ISH and RILU seriously objected Hardy's volte-face, and that his time as ISH President and leading SMM organiser was running out. Hardy travelled to Hamburg and attended the ISH World Congress. His visit in Altona left few traces. Official reports of the congress did not even mention Hardy's name but police informants knew better: Hardy had been dismissed. ${ }^{73}$

69 (Half-burnt copy of letter) Padmore to Mahon, 13.1.1932, George Hardy personal file, KV $2 /$ 1027, TNA.

70 (Half-burnt copy of letter) Padmore to Mahon, 1.2.1932, George Hardy personal file, KV $2 /$ 1027, TNA.

71 Padmore to "the Bureau of the ISH," [Hamburg] 24.3.1932, 534/3/754, 187, RGASPI.

72 (Half-burnt copy) Inf. note, [...] 32 , George Hardy personal file, KV 2/1027, TNA.

73 (Half-burnt copy) S.B. Inf, no date (May 1932), George Hardy personal file, KV 2/1027, TNA. 
Returning to England, Hardy faced another setback. On 11 June, Walter informed the Minority Movement that the ISH Secretariat and the RILU European Bureau had decided to terminate Hardy's assignment to the ISH and the SmM: "We are instructed to let you know that with the end of the month of June the work of comrade Hardy for the I.S.H. expires. At the same time comrade Hardy is to be given to the disposal of the British movement. Will you please take notice of this and arrange for the necessary steps." ${ }^{74} \mathrm{~A}$ few weeks later, Hardy had to accept the nomination of Alec Robson (1895-1979) as new national leader of the SMM and member of the Is H Executive Committee by the CPGB. ${ }^{75}$ However, Hardy's removal as leader did not clear the air as some SMM members, the so-called Hardy fraction, remained loyal to him. Walter tried to find a solution to the deadlock situation by sending an instructor to England in early July, and travelled himself to London for a meeting with the leaders of the Minority Movement and the SMM. In Walter's mind, the discussions had validated the decision to dismiss Hardy. ${ }^{76}$ On 8 July, comrade Allen informed the ISH that the Minority Movement had confirmed "the termination of the work of comrade Hardy as leader of the SMM [...] and to ask comrade $\mathrm{K}$. to assume responsibility and to bring forward to our next meeting a plan of future work." ${ }^{77}$ Comrade K was probably the Australian mariner Joe Keenan whom the ISH Secretariat had nominated to reorganise work on the waterfront in the United Kingdom. ${ }^{78}$

Hardy protested and demanded a written explanation about his removal. Walter sent him an official reply, listing the reasons for the decision: 1) fruitful cooperation between him and the IsH was not anymore possible, 2) totally divergent opinions about the leadership and development of the organisation in England, 3) his activities in England had undermined the expansion of the revolutionary opposition in England, and 4) there existed no prospects for

74 The original letter has not (yet) been identified. References to it are found in (Half-burnt copy of letter) ISH to SMM, 11.6.1932, George Hardy personal file, KV 2/1027, TNA; quotation from Albert Walter to "Werte Genossen," [Hamburg] 18.10.1932, 534/5/231, 44, RGASPI. (Half-burnt copy of letter) Hardy to H. Lee, 25.6.1932, George Hardy personal file, KV $2 /$ 1027, TNA. On Robson, see Martin Levy, "Alec 'Spike' Robson," https://www.communistparty.org.uk/alec-spike-robson/ (checked 14.12.2020).

76 Albert Walter to "Werte Genossen," [Hamburg] 18.10.1932, 534/5/231, 44, RGASPI.

77 (Half-burnt copy of letter) Allen to IsH, 8.7.1932, George Hardy personal file, KV $2 /$ 1027, TNA.

78 According to an intelligence memo, Keenan had succeeded Hardy at the SMm, (Halfburnt copy) Inf. note, 21.7.1932, George Hardy personal file, KV 2/1027, TNA. See further Comment by Gallagher in Kommission der Seeleute und Hafenarbeiter, 8.12.1933, 495/171/ 313, 39-47, RGASPI. 
fruitful work in England as long as he headed the SMM. ${ }^{79}$ Pechmann received a copy of the letter, and immediately informed the RILU headquarters that the crisis in England had been solved. ${ }^{80}$

Case closed? Walter returned to Hamburg and ordered the ISH instructor to initiate the revitalisation of activities in Britain. The ISH instructor was Richard Krebs, who used the alias James Anderson while residing in the United Kingdom. Krebs' orders were to enforce the transformation of the SMM into a red union by dismissing Hardy's fraction in the smm leadership and its local branches in Cardiff, Glasgow, Hull, Liverpool and London. ${ }^{81}$ Hardy vehemently objected the ISH intervention and protested to the Political Bureau of the CPGB. ${ }^{82}$ In his mind, the whole mess had been caused by the infiltration of "Trotskyists" in the IsH Secretariat, notably Adolf Shelley, ${ }^{83}$ and called the Political Bureau to probe the ISH decision to intervene. ${ }^{84}$ Krebs, in turn, overruled the protests, organised meetings in Cardiff and Liverpool, and decided to launch the Unity Movement of Seamen, Port-Workers and Fishermen at a forthcoming national conference in September. ${ }^{85}$

The radical plans for launching a red union in the United Kingdom never materialised. On 3 September, the police arrested Krebs when he arrived in Glasgow. Realising him carrying a forged passport, the police ordered his expulsion from Britain. ${ }^{86}$ Krebs' return to Hamburg resulted in the collapse of

79 To comrade Hardy, [Hamburg] 23·7.1932, 534/5/231, 45, RGASPI.

80 Leo [Pechmann] to "Werte Genossen," 534/4/405, 45, RGASPI.

81 Anderson [Krebs] to "Lieber Freund," 9.8.1932, Richard Krebs personal file, KV2/1102, TNA.

82 Anderson [Krebs] to "Lieber Freund," 23.8.1932, Richard Krebs personal file, KV2/1102, TNA; Hardy to Lozovsky, London 29.1.1933, 534/7/54, 1, RGASPI.

83 In Hardy's mind, Shelley and Walter, not himself, were to blame for the chaos in England as their strategy rested on unrealistic expectations about fixing a concrete date for the establishment of the new seamen's union in England. Their depiction in his - biased autobiography reflects his deep mistrust in the two comrades; terming Walter a "waverer and opportunist," and Shelley as a "sectarian, Trotskyite;" see Hardy, Those Stormy Years, 216-217. Interestingly, Hardy does not discuss his dismissal from the ISH and his quarrel with the Political Bureau of the CPGB in his autobiography.

84 Hardy did not realise that he had a weak position in the CPG B leadership. The party nominated a commission to investigate Hardy's protests. To his bug surprise, the commission turned against him. Although it declared Hardy's "general line" to be correct and condemned "the arbitrary method adopted by the I.S.H." in his removal, it accused him for subjectivity in relation to Thompson, and for being obsessed about a conspiracy against him. See Copy of a document starting "The following points were considered by the Commission," copy attached to George Hardy's dispatch to Lozovsky, January 1931, filed in 534/7/54, 20-22, RGASPI.

85 Anderson [Krebs] to "Lieber Freund," 3.9.1932, Richard Krebs personal file, KV2/1102, TNA.

86 Telegram 4.9.1932, Richard Krebs personal file, KV2/1102, TNA. 
the ISH intervention in England and the abortion of the national conference. The plan for launching a red union was quietly buried; what remained was a dysfunctional SMM.

Hardy's dismissal has hitherto been analysed by using his and Krebs' autobiographies. ${ }^{87}$ However, the ISH and British Intelligence sources used for the above description of the course of events corrects, and even refutes, to a large part the stories in the two autobiographies. Especially Krebs' claim that Harry O'Connell belonged to the Hardy faction and was the squealer who denounced him is dubious. O'Connell, for certain, had criticised the SMM leadership in public at the ISH World Congress for its lukewarm commitment to work among black and colonial seamen in Britain. In a private letter to Arnold Ward, O'Connell criticised Hardy to be "an imposter and misleader," and for blocking black organisers to be nominated to leadership positions. O'Connell further notified Ward that he had been the leader of the SMM in Cardiff for over a year and only an intervention at the ISH World Congress had made Hardy and his fellows to change their mind about him. ${ }^{88} \mathrm{Hardy}$, in turn, claimed O'Connell to belong to the Thompson fraction, to be of "a very doubtful character who made public statements to the effect that I am a police informer," and accused him to be an opportunist. 89

O'Connell certainly did not belong to the Hardy fraction but neither did he belong to Thompson's group. Krebs's intention to use O'Connell as the main organiser of colonial work in Britain was not a degradation or limitation of his work as some researchers have claimed. ${ }^{90}$ Rather, Krebs' plan was in

87 Among others, e.g., Waldenfels, Der Spion der aus Deutschland kam, 142-145; Featherstone, Solidarity, 94-95; David Featherstone, "Maritime labour and subaltern geographies of internationalism: Black internationalist seafarers' organising in the interwar period," Political Geography 49 (2015): 13 .

88 (Half-burnt copy of letter) H.O. O'Connell to A. Ward, 13.7.1932, George Hardy personal file, KV 2/1027, TNA.

89 Reply of Comrade G. Hardy to the Commission's Report set up by the Political Bureau of the C.P.G.B. to Investigate His Position, dated 4.1.1933, copy attached to George Hardy's dispatch to Lozovsky, January 1931, filed in 534/7/54, 11-12, RGASPI.

90 Adi, Pan-Africanism, 263; Featherstone, Solidarity, 95; Featherstone, "Maritime labour," 13; David Featherstone, "Anti-colonialism, subaltern anti-fascism and the contested spaces of maritime organising," in Anti-fascism in a Global Perspective: Transnational Networks, Exile Communities, and Radical Internationalism, eds. Kasper Braskén, Nigel Copsey and David Featherstone (London and New York: Routledge, 2020), 164. Makalani's (In the Cause of Freedom, 185) claim that O'Connell was "so irritated by his treatment that he resigned and refused even direct aid from Padmore and Kouyaté, choosing instead to form the Cardiff Coloured Seamen's Committee" is dubious; besides, the Cardiff Coloured Seamen's Committee was established in 1935. 
tandem with Padmore's and the IsH's demand to fully engage with black and colonial seamen throughout Britain. However, British Intelligence lured Krebs and other SMM members when they interrogated O'Connell, and spread the rumour that O'Connell was against Krebs' masterplan for the reorganisation of the SMM:

We are assumed to hear that Krebs thinks that he was given up by the Hardy-Thompson group. We rather hoped that he might put the blame on them, as there was a dispute ending in blows at the Seamen's Club in London which resulted in Police intervention. Hardy and the [N]egro O'Connell were taken to the Police station, and the remainder of the members of the Club were very much perplexed when O'Connell remained talking to the Police for an hour after the question of quarrel had been settled. ${ }^{91}$

Hardy had every reason to be disgruntled. Joe Keenan, ${ }^{92}$ who had been charged by the CPG B to run the SMM, and Richard Krebs had cut his funding and no salary had been forthcoming for months. In August, British Intelligence informants claimed that Hardy was "exceedingly 'hard up' " and was an ostracised person within the movement: "No one in the movement will advance him a loan or even the smallest amount, because of his unpopularity." Hardy appealed to Moscow and his old friend Lozovsky, openly declaring that his case was not yet closed "[...] Wait and see what EKKI has to say about me." Nothing happened; Moscow was silent. Hardy remained in control of his fraction, paralysing the SMM. In February 1933, rumours started to circulate that Hardy was about to be reinstated as leader of the SMM. The Minority Movement vehemently denied; instead, they suggested of sending him to Soviet Russia for medical treatment in a sanatorium (Hardy had been diagnosed heart problems) to get rid of him. However, Hardy's return as Sмm leader never materialised. Instead, he was back on CPGB-pay roll in March 1933 as assistant to Arthur Lewis Horner's electioneering campaign in South Wales. Moreover, he temporarily assisted the SMM in its blockade campaign during the Swedish seamen's

91 Cross-reference (original in Krebs personal file) 20.9.1932, George Hardy personal file, KV $2 / 1027,83 \mathrm{~B}$, TNA.

92 Joseph (Joe) Keenan, born in 1900 in Scotland, had arrived in Australia in 1921 and served as a seaman during the 1920s. In the early 1930s, he returned to the United Kingdom and worked as a communist union organiser. In 1934, he returned to Australia to propagate communist policies. See further L. T. Louis, "Recovery from Depression and the Seamen's Strike 1935-6," Labour History 41 (November 1981): 78. 
strike (see Chapter 8.2.1) and in its attempt to reorganise work among Indian seamen. However, Hardy's engagements in England ended in July 1933 when he embarked the MVJan Rudzutak and travelled to the Soviet Union. Returning in late November, Hardy never resumed as leader of the militant waterfront but started as manager at Collet's/The Political Bookshop in London. ${ }^{93}$

\section{$2 \quad$ Calling Black Seamen}

George Padmore reorganised work among colonial seamen in Hamburg when he started as ITUCNW Secretary. While the IS H Secretariat acknowledged the fact that Padmore's main interest focus was on the radicalisation of black workers in the Atlantic world, they underlined that work among black seamen was to be directed by the national sections of the ISH and not the ITUCNW. Therefore, work at the Colonial Section at the Hamburg Interclub was to be carried out as a combined effort of the Interclub functionaries and Padmore; it seems that Liao Chengzhi had left Hamburg at this point, as his name was not listed in the blueprint outlining the reorganisation in early March 1932. ${ }^{94}$ Nevertheless, work among Chinese seamen continued to pay off and the Chinese functionaries attached to the Hamburg Interclub were able to establish local branches of the Chinese Seamen's Union in Amsterdam, Antwerp, Hamburg, London, Rotterdam, the USA, and in Curaçao in the Caribbean. ${ }^{95}$

Marseille and Rotterdam emerged by 1932 as the strategically most important ports for work among colonial seamen. While Marseille evolved as a central hub for work among black, Arab and Vietnamese seamen as well as for connections with the French colonies in Africa and Asia, the Interclub in Rotterdam focussed on work among Chinese and Indonesian seamen and was in charge of connections with Indonesia and South-East Asia. Similar to activites in Marseille, the Interclub in Rotterdam received instructions and

93 (Half-burnt copy) Inf. notes, 11.8.1932; "A" [Krebs] to ISH, 23.8.32, 8.2.1933, 16.3.1933, 27.7.1933, 21.11.1933, George Hardy personal file, KV 2/1027, TNA. Hardy had sent a long letter to Lozovsky, dated 29.1.1933, where he attached copies of several documents in connections with his case, all filed in 534/7/54, RGASPI. However, Lozovsky failed to get the Hardy affaire on the agenda of the Political Commission of the ECCI. Instead, the ECCI Commission on work among seamen in December 1933 had the final word about the matter; see further Chapter 8.5.1.

94 Walter/Stein/Adolf, Vorschläge zur Stärkung der organisatorischen Arbeit der ISH, Hamburg, 3.3.1932, 534/5/230, 53, RGASPI.

95 Albert Walter, Kurzer Bericht des chinesischen Mitarbeiters im Interklub Hamburg, 12.11.1932, 534/5/231, 72, RGASPI. 
agitation and propaganda material not only from the ISH Secretariat but also from the RILU headquarters in Moscow. ${ }^{96}$

The central hubs for agitation among Chinese, Korean as well as Japanese maritime workers in the Pacific area were Vladivostok, Shanghai, San Francisco and Vancouver. Interclubs existed in all of the four port cities, although operating illegally in Shanghai. ${ }^{97}$ Both the RILU Secretariat and the ISH Secretariat tried to monitor their activities, among others by orchestrating the campaign against the Japanese attack on China in $1931-32$ as well as sending invitations for the Is H World Congress. ${ }^{98}$ Work among colonial seamen proved difficult at least in Vladivostok but the functionaries tried their best to disseminate the Japanese edition of the Pan-Pacific Worker ${ }^{99}$ Conditions for work among Chinese and Japanese maritime workers were slightly better in US Pacific ports. The ISH therefore shifted its focus to San Francisco where the American Bureau of the Pan-Pacific Trade Union Secretariat had been established in January $1932 .{ }^{100}$ ISH Secretary Walter stressed the American Bureau to expand its activities to Vancouver and start to work among Japanese and Chinese seamen. ${ }^{101}$

\subsection{Sensitising Black Seamen and Harbour Workers}

Part of the preparations for the upcoming World Congress was to sensitise African and Caribbean mariners and dockers about the need for them to

96 For example, Instructions from the RILU Eastern and Colonial Section to the ISH regarding a call to Indo-Chinese seamen in France [in German], Moscow 5.2.1932, 534/5/230, 26, RGASPI; Instructions from the RILU Secretariat to the RGO Holland concerning joint actions with the ISH among Malayan and Indonesian seamen, February 1933, 534/6/62, 14-16, RGASPI.

97 The (illegal) Interclub in Shanghai seems to have ceased operation in 1931 when the British secret service uncovered the clandestine Communist units and liaison persons. The Shanghai Interclub was not included in the list of Interclubs in early 1932; see ISH, Situationsberich 1.1.-15.2.1932, 534/5/230, 49, RGASPI.

98 RILU Eastern and Colonial Section to Comrade Kennedy, 25.1.1932, 539/4/412, 13, RGASPI, concerning an appeal to Japanese and Korean seamen about the forthcoming ISH Congress; Kennedy was head of the Pan-Pacific Trade Union Secretariat Bureau in Vladivostok. See also Simpson to Walter, 3.3.1932, 534/5/235, 19-20, RGASPI, concerning the ISH appeal on the Japanese attack on Shanghai; Simpson was head of the ISH Bureau in Vladivostok. The ISH Bureau in Vladivostok was most likely monitored by the ISH Sovbureau in Moscow, not the ISH Secretariat in Hamburg.

99 Report by Kennedy on work among Japanese seamen in Vladivostok, 14.2.1932, 534/4/415, 23-32, RGASPI.

100 Fowler, Japanese and Chinese Immigrant Activists, 92-94.

101 NN to the American Bureau of the PPTUS/San Francisco, 9.1.1932, 534/5/235, 107, RGASPI; Walter to "Werte Freunde," [Hamburg] 14.6.1932, 534/5/230, 121, RGASPI. 
cooperate under the umbrella of a radical platform. Garan Kouyaté informed about his attempts to organise black maritime transport workers in France already in the December 1931 issue of The Negro Worker. ${ }^{102}$ The March 1932 issue of The Negro Worker contained both an article by Kouyate about his agitation among black seamen in Marseille as well as an announcement of the forthcoming ISH World Congress. ${ }^{103}$ The French reformist trade union leaders, Kouyaté warned his readers, were mobilising white against nonwhite maritime workers by giving priority to French (white) mariners while demanding the repatriation of colonial and foreing seamen from France. Still, he asured his readers, the united front of revolutionary maritime workers was unshaken in France: Arab, black, and Vietnamese mariners were coming in hundreds to the meetings of the local branches of the FUMP and were supporting the call of a united front on board the ships. "In this way we shall not only develop their understanding for economic struggles, but we shall also strengthen the united front between the white and coloured workers against wage cuts, against unemployment, starvation and against all ministerial decrees - the originators of which are in reality the trade union reformists," he declared.104

Finally, an "Appeal to Negro Seamen and Dockers" was published in the April 1932 issue of The Negro Worker. ${ }^{105}$ Officially in the name of the ISH, the 1932 Appeal had perhaps been drafted by Padmore but certainly circulated via the RILU Secretariat ${ }^{106}$ - another example of the close collaboration between the ITUCNW and the ISH. In line with its earlier declarations, the 1932 Appeal started by underlining the unity of "White, Black and Yellow water transport workers" and invited them all to participate at the planned world congress of the ISH. Noting that the "Negro workers in Africa, England, France, America, and the West Indies are among the worst paid and treated slaves of the shipowners and other capitalists," the invitation to participate was especially directed to them. ${ }^{107}$

\footnotetext{
102 G(aran) Kouyaté, "Black and White Seamen Organize for Struggle," The Negro Worker 1, no. 12 (1931): 19-20.

103 G(aran) Kouyatte [Kouyaté], "Solidarity Between White and Coloured Sailors," The Negro Worker 2, no. 3 (1932): 27-28.

104 Kouyatte, "Solidarity Between White and Colonial Sailors."

105 "Appeal to Negro Seamen and Dockers," The Negro Worker 2, no. 4 (1932): 20-24.

106 This is indicated by Otto Huiswoud's inquiry to Padmore whether he had received a copy of the appeal and if he had it printed. Huiswoud to Padmore, 21.2.1932, 534/3/754, 124, RGASPI. A draft version of the 'Appeal to the Negro Seamen and Dockers' is filed in 534/5/ 223, 175-183, RGASPI, implying that it was prepared sometimes in late 1931.

"Appeal to Negro Seamen," 20.
} 
Next, the 1932 Appeal highlighted the exploitation of colonial seamen on board and the increasing number of unemployed African, African American and Caribbean maritime workers in America, the United Kingdom and France. Their misery had been caused by the economic depression and crisis of the shipping industry but it had been worsened by the actions taken by shareholders and directors of the shipping companies by lowering the wages of the maritime workers and applying a policy of 'divide and rule', i.e., playing white seamen against black and "yellow" ones. Not surprisingly, the Appeal launched a broadside attack against the national unions and their leaders who were accused to back the policy of the Capitalists and to foster race hatred among the white seamen and harbour workers against their "colonial class brothers." The worst plight, the Appeal acknowledged, was felt by the black seamen, they were given the heaviest and dirtiest work, were paid lower wages than white seamen, they received the worst food and had the most terrible working conditions. Therefore, the Appeal underlined that the ISH had called the white classconscious workers to join hands with their "coloured brothers in America and in the colonies" to fight against the exploitation of the bosses, against unemployment, wage cuts and the lengthening of working hours. What mattered in the end was the "united front of all seamen and dockers irrespective of colour, nationality or race." 108

Who were these black seamen and to whom was the $193^{2}$ Appeal directed? As it was published in The Negro Worker, it had spread throughout the Atlantic world and was read in the USA, the Caribbean and in Africa. It criticised and condemned working conditions in the Atlantic world - the "betrayal" of reactionary union leaders in the USA, the exploitation of black maritime workers in African and Caribbean ports by the European shipping industry. The Appeal reminded that the 'reformist' national unions in the United Kingdom and France had turned their back to the black workers. Instead, the black seamen and harbour workers were reminded that the only organisation that defended their rights and called them to join their ranks was the revolutionary trade union movement, namely the ISH and its affiliated sections such as the MWIU, the SMM, the CGTU, and the African Federation of Trade Unions in South Africa. ${ }^{109}$

While most of the 1932 Appeal echoed the ISH Colonial Resolution of 1931/ 32 , its last paragraph integrated a new element which had been absent in the resolution, namely the call to boycott the transport of war material to the Far

\footnotetext{
108 "Appeal to Negro Seamen," 21.

109 "Appeal to Negro Seamen," 22-23.
} 
East. This urge was linked to the campaign by the Comintern and RILU against the Japanese attack on China in September $1931{ }^{110}$ Following the 1928 adopted Imperial War Theses of the Comintern, the Manchurian Crisis was interpreted and presented in the Appeal as part of a planned imperialist attack on the Soviet Union, "the only country ruled by the working class, the only country which is constructing a new socialist regime, free from exploitation, oppression, race hatred and unemployment."111

The 1932 Appeal ended with a six-point list of demands which the Is $\mathrm{H}$ called the black seamen to join its rank and files: to fight against discrimination of black seamen in the national unions, for equal pay for equal job irrespectively of race, colour or nationality, and for increasing the wages of colonial seamen. Further, black and white maritime workers were called to work for a threeshift system for the men on deck and four-shifts for the men under deck, seven hours' day during the watch, one free day on shore for every Sunday spent on the journey, social insurance at the expense of the ship owners and the State, unemployment benefit as well as free food, cloths, shelter for the unemployed. Last, but not least, the black maritime workers were urged to organise revolutionary ship and dock groups, and to join the national sections of the IS H. ${ }^{112}$

\subsection{The Rise and Collapse of Work among Black Seamen in England}

Agitation among colonial maritime transport workers was slow to commence in the United Kingdom. Several plans had been put forward but the communists had gathered few followers among them, neither in the CPG В nor in the Minority Movement. The SMM, too, appeared at first as a mainly white radical movement. The only potential opening was the Indian Seamen's Union in London, listed by the ISH as a "sympathising" organisation, i.e., an organisation not directly controlled by the party or the communists. Still, the ISH regarded the Indian Seamen's Union as its main vehicle for agitation among Indian seamen and, most importantly, as a vital cog for the formation of a red seamen's union in India. However, the revelation that most of its 1,500 members were either inactive or only loosely connected to it, and that the association itself was not very well organised, damped the expectations of the ISH Executive Committee in their assessment of the state of affairs in England in September 1931. ${ }^{113}$ To boost agitation among Indian seamen, the ISH Executive Committee instructed the London Interclub start systematic

\footnotetext{
110 See further Chapter 6.5.4.

111 "Appeal to Negro Seamen," 24.

112 "Appeal to Negro Seamen," 24.

113 Zweite Plenartagung der Executive der IS H, 1O-12.9.1931, 534/5/224, RGASPI.
} 
work among Indian seamen, to intervene in the Indian Seamen's Union and initiate a reorganisation of its work, and together with the association issue "suitable literature" for the Indian seamen. ${ }^{114}$

Arab (Yemeni) and Somali mariners were an equally important target group for the SMM. Most of them resided in South Shields and Cardiff. Radicalisation among the Arab mariners had gained momentum during the latter part of the 1920 s as part of challenging the "white labourism" of the NUS. The protests culminated in 1930 when the NUS declared that Arab and Somali mariners, specifically, should be picked last, if at all, and go on a forced rota, i.e., they had to take any job offered them. Violent clashes followed in Cardiff and South Shields. The Smm supported their protests, hoping to win Arab seamen into its ranks. ${ }^{115}$

Black maritime transport workers were another focal group. The SMM achieved to enlist several black radical union activists among its ranks, most notably the Barbadian Christ Braithwaite (who used the pseudonym Chris Jones as militant activist), Harry O'Connell from British Guiana, and Ebenezer Foster Jones from Sierra Leone. In autumn 1930, Nigerian radical nationalist and trade union activist Frank Macaulay, who had earlier in the year participated at the Hamburg Conference and the RILU World Congress, arrived in England. Ordered by Ford and Padmore to start a campaign among black workers, he stayed in Cardiff and organised meetings for black maritime transport workers before returning to Nigeria in early 1931. Although impressed by his methods, the SMM was critical that his sojourn had resulted into the formation of a 'Negro Welfare Organisation' rather than enlisting black seamen into the ranks of the SMM. ${ }^{116}$ Instead, it was to be the task of O'Connell, Braithwaite/ Jones and Foster Jones to campaign among black seamen and harbour workers in Liverpool, Cardiff and London. Organised work started in November 1931 when sмm Secretary Fred Thompson called a meeting at the London Interclub. Although only seven black seamen turned up, the participants resolved to form

\footnotetext{
114 Decisions of the II. Plenary Session of the Executive Committee of the I.S.H. on the Activity and tasks of the International Seamen's Clubs, September 1931, 534/5/224, 198, RGASPI.

115 Richard I. Lawless, "Religion and politics among Arab seafarers in Britain in the early twentieth century," Islam and Christian-Muslim Relations 5, no. 1 (1994): 35-56; Hassan Mahamdallie, "Muslim working class struggles," International Socialism: A quarterly review of socialist theory, Issue 113, posted 4.1.2007, https://isj.org.uk/muslimworking-class-struggles/ (checked 21.5.2020). See also Richard I. Lawless, From Ta'izz to Tyneside: An Arab community in the North-East of England during the early twentieth century (Exeter: University of Exeter Press, 1995).
}

116 Featherstone, "Maritime labour," 12. 
a 'Negro Committee', and elected the Trinidad-born mariner Jim "Jas" Headley as secretary. ${ }^{117}$

The 'Negro Committee' did not exist for long by name as its members "emphatically" declared to Thompson that the term "Negro" should be scrapped and the term "coloured" used instead. Thompson backed the proposition and argued that "to bring the position of the Negro seamen in British ships into a pamphlet, without bringing in the rest of the coloured workers sailing in British ships, is extremely likely to widen the division that already exists between Negro seamen and the rest of the coloured seamen." Vigorously he added, "Let me make this clear. The Negro seamen sailing in British ships claim they are British subjects and for this reason have the right to preference of employment over Arabs, Egyptians, Sonalies [sic], etc."118 These conditions paralleled to those described a few years earlier by Dumay in his description of the state of affairs in France - French colonial subjects claimed to have the same rights as white French mariners. Besides, the SMM, too, at least in principle adhered to the RILU and ISH directives to stamp out white chauvinism and discrimination among its ranks.

News about the prospective developments in England reached Moscow and Huiswoud informed Padmore in January 1932 that the Anglo-American Section of the RILU had decided to nominate Jim Headley, whom he labelled "a Negro comrade in England," to be responsible for the work, and that he should head a special committee to coordinate work in England. ${ }^{119}$

The 'Negro Committee' and its local organisers in London (Jim Headley and Chris Jones), Cardiff (Harry O'Connell) and Liverpool (Foster Jones) made substantial progress, and some 6oo black mariners were reported to have been recruited to the SMM by $1932 .{ }^{120}$ However, the crisis in the SMM between the Hardy and Thompson factions negatively affected work among black and colonial seamen. The problems in the UK were finally scrutinised at the World Congress of the ISH in May 1932, resulting in harsh critique of the SMM by Padmore and O'Connell at the congress for it neglecting work among black and colonial seamen. ${ }^{121}$ Padmore accused the SMM for having totally failed in its work among colonial seamen and summarised O'Connell intervention at

117 Fred Thompson to George Padmore, [London] 20.11.1931, 534/5/223, 47, RGASPI.

118 Fred Thompson to George Padmore, [London] 28.12.1931, 534/5/223, 123, RGASPI.

119 Huiswoud to Padmore, 6.1.1932, 534/3/753, 34, RGASPI.

120 (Ford), ITUCNW Report 1930-1931, 534/3/669, 229, 232, RGASPI; (Padmore), ITUCNW Report 1931-1932, 534/3/753, 124, RGASPI; Draft resolutions on the work of the Hamburg TU Committee Nov. 31-32, no author, 13.12.1932, 495/155/100, 29, RGASPI.

Featherstone, "Maritime Labour," 11-13; Høgsbjerg, "Mariner, Renegade \& Castaway," 36. 
the IsH World Congress - the latter had been able to rally more than 500 black, Arab and Somali seamen into the ranks of the SмM but due to political confusion and "opportunistic tactics" the colonial seamen had drifted away from the organisation. ${ }^{122}$

Walter's detachment of Richard Krebs to intervene in the crisis of the SMM also affected Chris Jones' and Harry O'Connell's position within the SMM. Apart from forcing Hardy to resign, Krebs also tried to find a solution to the pathetic state of affairs in Cardiff and London. Krebs believed O'Connell to belong to the Hardy faction and criticised him for blocking his followers to join the reorganised SMM section in Cardiff. ${ }^{23}$ A total break was avoided as Krebs threatened O'Connell at a meeting "either to stop his tricks or be kicked out", and the latter "promised to stop his tricks and work together with the rest." One day later a conference was held in Cardiff where O'Connell was given the task of organising colonial committees in Cardiff, Newport, Swansea and Barry as well as to organise groups of 'Negroes' visiting ships. Moreover, Krebs asked O'Connell to organise a district meeting of colonial seamen. ${ }^{124}$

Chris Jones, on the other hand, was less fortunate. Krebs informed Albert Walter in early September that he had expelled Jones from the SMM, and asked for his expulsion from the СРGв. Krebs accused Jones for working as a police informant or at least on commission for the NUS, and for lending out money "at fabulous interest" to seamen. Jones, in an interview with Krebs, acknowledged on the other hand that he had received "certain instructions" from "a Negro comrade from Hamburg," and frankly refused to tell Krebs anything more. ${ }^{125}$ Krebs removed Jones but whether the Hamburg connection led to any investigations by the ISH is not known as Krebs was arrested the same day (3.9.1932) he informed Albert Walter about the turn of events in England and was deported from the country.

The attempt to organise black seamen and harbour workers under the SMM in England never materialised. Padmore was aware of the problems and suggested a merger between the 'Negro' Committee of the SMM and the Negro

\footnotetext{
122 George Padmore, "World Congress of Seamen," The Negro Worker 2, no. 6 (1932): 23-25.

123 Intercepted letter from Anderson [Krebs] to "Dear Friend" [probably Albert Walter as the original letter was written in German], 23.8.1932, TNA KV 2/1102. Krebs describes O'Connell in aggressively racialised terms; see Featherstone, "Maritime labour": 13, and Featherstone, "Harry O'Connell," 77.

124 Intercepted letter from And[erson] to "Dear Comrade," 27.8.1932, TNA KV 2/1102. According to another intercepted letter, 20 Negro seamen participated in the Cardiff conference (of a total 200 participants).

125 Intercepted letter from And[erson] to Albert Walter [English translation], 3.9.1932, TNA KV $2 / 1102$.
} 
Welfare Association (NWA) ${ }^{126}$. In this way, he envisioned, the NWA could be developed into a strong organisation and as the British section of the ITUCNW. However, such hopes were futile. Headley returned to Trinidad in 1932, resulting in the collapse of activities of the SMM 'Negro' Committee in London. ${ }^{127}$

\subsection{Closing the Chapters?}

Padmore was rather critical about the cooperation with the ISH and its national sections. In his mind, all talks about mutual assistance were only lip service:

The ISH sections, in England SMM, in France and USA, have done little or nothing to facilitate the carrying on of our work thru their organisation. We have made repeated appeals to them during 1932 to help us to distribute our literature thru their clubs. ${ }^{128}$

Padmore notified the RILU Secretariat that the Interclub in New Orleans was the only unit in the USA that assisted the ITUCNW. On the other hand, through the Interclub, connections had been established with Caribbean seamen. An embryo for a future Caribbean connection, therefore, seemed to be evolving. ${ }^{22}$

Cooperation between Padmore and the ISH Secretariat turned sour after the World Congress. The trigger was Padmore's harsh letter to the ISH Secretariat in early August 1932 where he criticised Walter and Polano for not answering to his inquiries and for not forwarding him any funds to cover the cost of posting the ITUCNW-journal. Padmore had received letters from British Guiana and South Africa and wanted to take actions. The first was a note from the Labour Union of British Guiana about their plans to organise a strike among dockers and them accepting the leadership of the ITUCNW. Padmore was exited, this would have opened the doors for the ITUCNW to assume a political role it hitherto never had taken. "We think that the ISH is in a position to help them, and would therefore like to get your opinion so that we may write them at once," Padmore informed the ISH Secretariat. Furthermore, Padmore had received a report from South Africa and had forwarded "certain recommendations" to the ISH Secretariat. ${ }^{130}$ Although not stated in

126 The Negro Welfare Association had been formed by Chris Jones and Arnold Ward in 1931, see Høgsbjerg, "Mariner, Renegade \& Castaway," 44. Arnold Ward, born 1886 in Barbados, was the NWA's secretary and one of Ford's and Padmore's key contact persons in England.

127 Adi, "The Comintern and Black Workers," 235.

128 (Padmore), ITUCNW Report 1931-1932, 534/3/753, 127, RGASPI.

129 (Padmore), ITUCNW Report 1931-1932, 534/3/753, 127, RGASPI.

130 Padmore to the Bureau of the ISH, [Hamburg] 1.8.1932, 534/5/231, 2, RGASPI. 
Padmore's letter, the South African information concerned the establishment of Interclubs in Cape Town and Durban as well as the prospect of forming a radical seamen's union. In late October, the Ecci Emissary to the Communist Party of South Africa, Eugene Dennis, reported that a seamen's and harbour workers' union had been formed in South Africa. The union claimed to list over 250 members (although Dennis had to admit that 100 of them already had become passive due to the shortcomings of the CPSA in the Cape Town district), had "fairly strong" committees in Durban and Cape Town, and had established seven ship committees and one dockers' group. Most importantly, 90 percent of the members did not belong to the party but counted influential communist fractions in Durban and Cape Town. The union had also opened Interclubs in the two aforementioned ports. ${ }^{131}$ Interestingly, it seems as if the Is H Secretariat had not received the news from South Africa. Be as it may, in early December Walter notified about the formation of an Interclub in Cape Town - but for reasons not known, not about the activities in Durban. ${ }^{132}$ In addition, Padmore had perhaps been informed about the plans to organise a strike in Durban among the whaling fleet, and wanted to discuss this matter with Walter. However, nothing came out of these plans due to the early closing of the whaling season in $1932 .{ }^{133}$

The third issue Padmore wanted to discuss was the situation in England:

After comrade W[alter]'s return from E[ngland] we had a conversation on the colonial work of the SMM in that country. He told me of the unsatisfactory state of affairs which we are well acquainted with, in view of the fact that we made a complete survey and prepared a detailed report for the ISH which you have never discussed with us. In order to improve the situation we would like to make certain concrete recommendations to you which comrade W[alter] had asked us to formulate. We would therefore like to discuss this question as early as possible. ${ }^{134}$

131 Letter from E. Dennis to Comintern, 22.10.1932, published in Apollon Davidson, Irina Filatova, Sheridan Jones and Valentin P. Gorodnov, South Africa and the Communist International: A Documentary History, Vol. II (London/Portland, OR: Frank Cass, 2003), 38-39.

132 Walter to "Werte Genossen," [Hamburg] 2.12.1932, 534/5/231, 78, RGASPI.

133 Letter from E. Dennis to Comintern, 22.10.1932, published in Apollon Davidson, Irina Filatova, Sheridan Jones and Valentin P. Gorodnov, South Africa and the Communist International: A Documentary History, Vol. II (London/Portland, OR: Frank Cass, 2003), 39 .

134 Padmore to the Bureau of the ISH, [Hamburg] 1.8.1932, 534/5/231, 2, RGASPI. 
No immediate reaction from the ISH office. Padmore sent further inquiries and was notified that Walter had left for vacation. Further irritation - or was it the ultimate trigger (?) - for him was his lack of funding:

We must draw your attention to the failure of the ISH to carry out the instructions of the RILU Executive with respect to supplying us with stamps for our work. [...] I have brought this matter to the attention of comrade W[alter] on several occasions. But since the condition still remains unimproved we would like you to take up this matter immediately ${ }^{135}$

Padmore received a stiff reminder two days later from comrade Henri, i.e., Luigi Polano. Indeed, "it is quite true that contact between us has been rather difficult lately," he replied but noted that this had not only been the fault of the leading comrades of the ISH as they "cannot find you when necessary." They had sent him a message to call them at the Interclub, and Polano had been waiting from 27 to 29 July every evening, but Padmore never turned up. Besides, Walter had been in his office every day until he left for vacation on 1 August. "From this you will perceive that, if you were anxious to meet one of the leading Comrades of the Is $\mathrm{H}$ you had ample opportunities to do so." In addition, regarding Padmore's complaints about funding, Henri stressed that a) the ISH had at present not the necessary money to provide the amount of postage required, and b) "because up till now no refunding has taken place to us of all the expenses incurred on your account."136 The second part was in fact an accusation of either Padmore overusing his account or, more likely, that funding from Moscow to cover for his activities had not been forthcoming, and the ISH had so far covered the expenses of the ITUCNW from its own funding.

Besides, Henri reminded Padmore that the pressing issue of how to handle the affairs in British Guiana and South Africa had been discussed at a meeting with Adolf Shelley on 2 August. "We can only confirm the suggestions and propositions made by Comrade Ad[olf]."137 Unfortunately, the minutes of the

135 Padmore to the Bureau of the ISH, [Hamburg] 1.8.1932, 534/5/231, 2, RGASPI.

136 Henri to Padmore, [Hamburg] 3.8.1932, 534/5/231, 4, RGASPI. The identity of Henri in this letter is dubious. I assume it is Luigi Polano who used the alias Henri Maurice. However, Henri refers to "Henry" in the letter (as did Padmore in his) and based on references to Henry in other letters and reports, I conclude that "Henry" is used by Shelley and Walter, among others, when referring to Luigi Polano. Thus Henri and Henry were most likely not two persons but one and the same, namely Polano.

137 Henri to Padmore, [Hamburg] 3.8.1932, 534/5/231, 4, RGASPI. 
meeting were either not sent to Moscow or are archived somewhere else. Was Shelley's reply that Padmore was fishing in another organisations' water?

Notwithstanding Padmore's criticism of the weak cooperation between the ISH and the Hamburg Committee, the RILU continued to stress the strategic relationship between the ISH and the ITUCNW. In a draft outline of guidelines for the ITUCNW in December 1932, any deviation from the 'United front from below'-tactic were ruled out:

The already established contacts and those which will be extended to the Negro seamen should be considered chiefly from the view point of the work of the latter in their native ports. On the basis of an agreement with the International of Seamen and Harbour Workers, they should be given concrete directives on the organisation of marine transport workers and on conducting the mobilisation of the workers for the struggle for their day to day demand. ${ }^{138}$

Especially the next paragraph can be read as Moscow's criticism about the state of affairs - the ISH for being inactive, Padmore for trying to disengage the black seamen from the Is $\mathrm{H}$ and to develop a parallel network of his own:

In order to successfully conduct this work [i.e., the mobilisation of black seamen] it is necessary to establish closest relations between the Hamburg Committee [i.e., the ITUCNW] and the ISH with its sections. The Negro Committee [of the SMM] jointly with the ISH should write special appeals and leaflets, dealing with the problem of the Negro seamen, these leaflets should be widely distributed through the port clubs. The Negro seamen should be directly organised in sections, ship and port committees of the ISH. It must be noted that the Hamburg Committee should by no means try to isolate the Negro seamen and dockers from the revolutionary organisations and the ISH. ${ }^{139}$

Consequently, the December 1932 statement once again underlined the decision of the Political Commission of the Comintern that the ITUCNW was not to be developed into a Black International. Padmore, it seems, had started to

${ }_{13} 8$ The International Negro Workers' TU-Committee, [.].XII.32, 534/3/753, 155, RGASPI. The document seems to have been written in Moscow after Padmore had delivered his annual report for 1932 while he was in Moscow in November/December that year. It is likely that it was commissioned by the RILU secretariat.

139 The International Negro Workers' TU-Committee, [.].XII.32, 534/3/753, 155, RGASPI. 
deviate from the official line and was reminded about who made the decisions and who was to implement them.

\section{$3 \quad$ Full Speed Ahead?}

The ISH World Congress was the visible manifestation of the radical maritime transport workers and envisioned a unified front against the assault of the shipping industry. Lessons learned so far from the economic and political struggles against capitalist and colonial exploitation as well as imperialist aggression was that international proletarian solidarity could only be promoted by cutting the ties with the national trade union leaders and the ITF. Course was set on full confrontation with the 'social fascists' and the transformation of the ISH into a full-fledged mass organisation by either conquering existing unions from within or establishing rivalling red union.

The realisation of this vision proved hard to achieve. Apart from the promising developments in Denmark, the red unions were either insignificant (USA), weak (France), or marginal (Germany). The attempts to launch a red union in the United Kingdom had been aborted and the intervention of the ISH had ended in a failure. A similar setback occurred in France where the police had arrested Luigi Polano immediately after his arrival in Paris in early August $193^{2}$ and had to return to Hamburg. ${ }^{140}$ As the ISH Secretariat did not have any funds to pay the salary of a third secretary, Shelley and Walter proposed that Polano was sent to either Latin America or the Iberian Peninsula. A third alternative was to nominate him as head of the ISH Sovbureau in Moscow. ${ }^{141}$ The RILU Berlin Bureau discussed the proposal in late December, and Pechmann advocated his transfer to Moscow. ${ }^{142}$

Another crucial matter to be resolved was the maintenance of a secure and reliable communications network. Intra-European contacts were rather easy to establish while extra-European ones, especially transcontinental links with the sections and units in the Pacific region, proved challenging. The Hamburg Interclub, in turn, was instructed to recruit reliable liaison persons serving as couriers of messages and instructions from Hamburg to China, Indochina, Japan and Korea. ${ }^{143}$

\footnotetext{
140 Leo to "Werte Genossen," 5.9.1932, 534/4/405, 45, RGASPI.

141 Walter to "Werte Genossen," [Hamburg] 9.11.1932, 534/5/231, 71, RGASPI; [Shelley, Walter and Polano,] to "Werte Genossen," no date [ca. December 1932], 534/5/231, 82, RGASPI.

142 Leo [Pechmann] to "Werte Genossen," 25.12.1932, 534/4/405, RGASPI.

143 ISH Sekretariat to "Sekretär des Interklubs und Leiter der Sektion der ISH," Hamburg 18.11.1932, 534/5/235, 131-133, RGASPI.
} 
However, it is questionable if the IS $\mathrm{H}$ headquarters ever supervised activities in the Pacific region. The Pan-Pacific Trade Union Secretariat in Vladivostok had opened a bureau in San Francisco in June 1932 and instructed it to assist the ISH in its agitation and propaganda work among Chinese and Japanese seamen, among others by publishing a Chinese and Japanese version of The Pan-Pacific Seaman. ${ }^{144}$ Work in the port was delayed and only started during autumn. ${ }^{145}$ At this point, the head of the San Francisco bureau notified Walter that the bureau was not an office of the ISH. ${ }^{146}$ Walter critically responded and demanded the comrades to consolidate their activities along the US West Coast and to establish Interclubs in Seattle and Vancouver. ${ }^{147}$

The limited capacities of the ISH headquarters in Hamburg to monitor activities in the Pacific region raised concern at the Pan-Pacific Secretariat of Transport Workers. Direct connections between Hamburg and the units in Vladivostok, the Interclub and the Pan-Pacific Trade Union Secretariat, had failed to be established, and no answers had been received from Hamburg on how to mobilise the organisations in the Pacific region. A correction to the dysfunctional connections was outlined at a meeting in Moscow in December 1932. According to the plan, the ISH Sovbureau in Moscow was to assume the role as a liaison centre as direct communications with Hamburg proved difficult to establish. However, for reasons not known, the implementation of the plan was delayed. Even worse, communications between Vladivostok and Moscow, too, were poor. In late March 1933, the secretary of the Pan-Pacific Secretariat of Transport Workers urged Luigi Polano, who at this point had relocated to Moscow and headed the ISH Sovbureau, to intervene: Inquire from Hamburg why the ISH had not sent any reply and notify the RILU headquarters about the difficulties of work in Vladivostok. ${ }^{148}$

The meeting at the RILU headquarters in December 1932 resulted in a new attempt to revise the organisational structure of the ISH. Work among maritime transport workers as well as the organisation of the ISH sections and the

\footnotetext{
144 Report on Pan-Pacific Trade Union Secretariat, [San Francisco] 8.6.1932, 534/4/423, 8-10, RGASPI; letter from "Eddy" to "Alex" about costs for printing The Pan-Pacific Seaman, [San Francisco] 11.6.1932, 534/4/423, 11-12, RGASPI.

145 "Eddy" to "Alex," [San Francisco] 1.9.1932, 534/4/423, 35, RGASPI.

146 American Bureau of the Pan-Pacific Trade Union Secretariat to the ISH, [San Francisco] 23.10.1932, 534/4/423, 42-43, RGASPI.

147 Walter to The American Bureau, Pan-Pacific Trade Union Secretariat, San Francisco, Hamburg, 9.11.1932, 534/5/235, 107, RGASPI; Plan for work among the Pacific marine transport workers, no date [ca. late autumn 1932], 534/4/423, 85-87, RGASPI.

148 NN, Pan-Pacific Secretariat of Transport Workers to Luigi Polano, ISH Sovbureau, Vladivostok 22.3.1933, 534/5/239, RGASPI.
} 
work of the revolutionary opposition within the trade unions was outlined in detail. Nevertheless, the directives remained a dead letter. Although they were sent to Hamburg in late 1932, Albert Walter was never capable to reply or even implement them. ${ }^{149}$

The RILU directives of December 1932 compelled Walter to summon the ISH Executive Committee for a meeting in conjunction with a regional conference of the radical waterfront in Scandinavia, the Scandinavian Maritime Unity Conference, see Figure 24, scheduled to be held in early January 1933. The venue for the meeting was the Copenhagen Interclub as the ISH Secretariat decided to focus on the Scandinavian countries where negotiations for new tariffs in the shipping industry were about to start. Hopes were high in Hamburg that the revolutionary trade union opposition would manifold its support as it was claimed that the rank and file members of the unions were discontent with their leaders. ${ }^{150}$

For reasons not known, the meeting of the ISH Executive Committee was cancelled, perhaps due to the incapacity of its members to travel to Copenhagen on a short notice. Besides, the date of the Scandinavian Conference had to be postponed to the end of January due to an intermezzo in Gothenburg. ${ }^{151} \mathrm{On} 22$ December 1932, the Swedish RFO had organised a demonstration in support of unemployed and jobless seamen that resulted in the storming of the building of the seamen's union in Gothenburg. The police intervened and the situation remained tense for the following weeks, interrupting the propaganda work of the Sjötransportarbetarnas RFO in support of the forthcoming conference. ${ }^{152}$

Eventually, the Scandinavian Conference materialised, and Pechmann, Shelley and Walter arrived at the Danish capital on 23 January 1933. The communist press hailed the conference as a "milestone" in the fight against the "offensive of the shipowners." Ninety-nine delegates attended the conference, almost all representing the red trade union opposition in the Scandinavian unions. Not surprisingly, the seamen's unions declined to send official

149 Die organisatorischen Aufgaben der ISH, 21.12.1932, 534/5/231, 125-130, RGASPI.

15 O Walter to "Werte Genossen," [Hamburg] 2.12.1932, 534/5/231, 78 - 81, RGASPI; Leo [Pechmann] to "Werte Genossen," [Berlin] 25.12.1932, 534/4/405, 77, RGASPI; Leo [Pechmann] to "Werte Genossen," [Berlin] 26.12.1932, 534/4/405, 84, RGASPI.

151 Walter to "Werte Kameraden," [Hamburg] 31.12.1932, 534/5/231, 168, RGASPI.

152 Weiss, För kampen internationellt!, 319-322. 


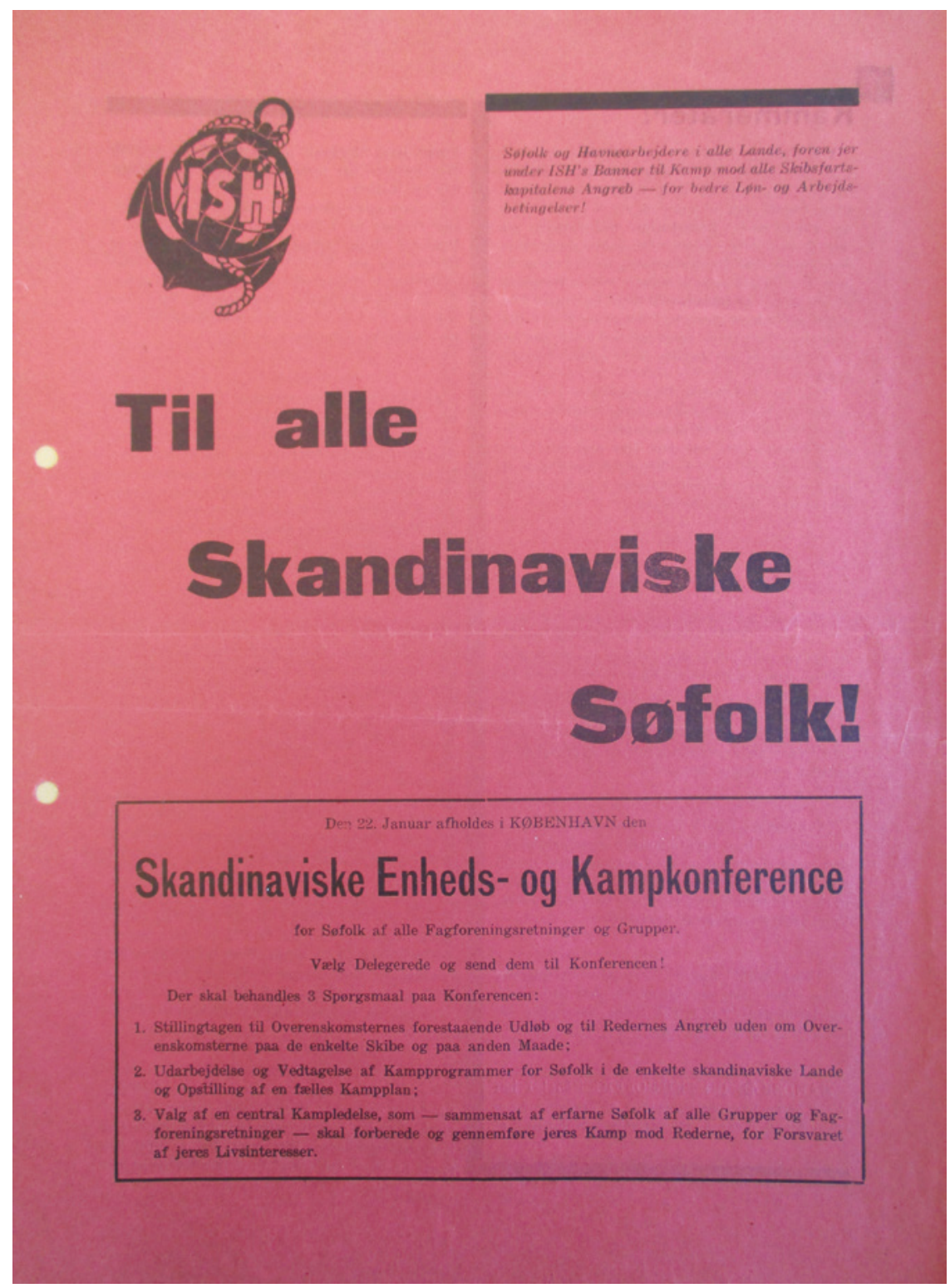

FIGURE 24 Flyer calling for the nomination of delegates to the Scandinavian Maritime Unity Conference, filed in 107 Richard Jensen Arkiv, Danish Labour Movement Library and Archives, Copenhagen. 
representatives. ${ }^{153}$ Pechmann critically remarked that the conference therefore missed the opportunity to manifest itself as a "unify from below."154 On the other hand, the conference reached its goals - the ITF and its regional counterpart, the Scandinavian Transport Federation (STF), were condemned as traitors of the working class and a declaration of demands for a new collective agreement and tariffs was adopted. Most importantly, strategies and tactics were outlined for the upcoming campaigns in Denmark and Sweden: National strikes and blockades were to be orchestrated internationally by the IS $\mathrm{H}$ and carried out in every port by its national sections. ${ }^{155}$

153 Weiss, För kampen internationellt!, 323.

154 Leo [Pechmann] to "Werte Genossen," [Berlin] 3.2.1933, 534/4/46o, 8-9, RGASPI. See also "Die Tagung der ersten Einheitskonferenz der skandinavischen Seeleute in Kopenhagen," Rote Wacht 4, No. 2 (February 1933).

155 Shelley to "Die führenden Genosen der Sektionen der ISH und Interklubs," [Hamburg] 30.1.1933, 534/5/236, 9, RGASPI. 